E International

\title{
Renegotiation of Transportation Public-Private Partnerships: The U.S. Experience
}

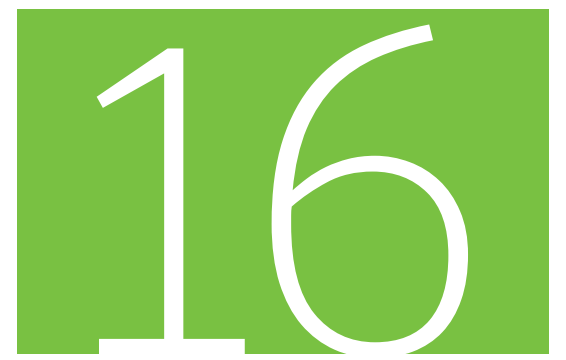

Discussion Paper 2014 • 16

Jonathan Gifford, Lisardo Bolaños, Nobuhiko Daito

George Mason University,

Arlington, VA, USA 


\title{
Renegotiation of Transportation Public-Private
} Partnerships: The US Experience

\author{
Discussion Paper $\mathbf{N}^{\circ}$ 2014-16 \\ Prepared for the Roundtable: \\ Public Private Partnerships for Transport Infrastructure: \\ Renegotiations, how to approach them and economic outcomes \\ 27-28 October 2014, \\ George Mason University, Washington D.C., USA

\section{Jonathan Gifford \\ Lisardo Bolaños \\ Nobuhiko Daito} \\ Center for Transportation Public-Private Partnership Policy \\ School of Policy, Government, and International Affairs \\ George Mason University \\ Arlington, VA. \\ USA
}

December, 2014 


\section{THE INTERNATIONAL TRANSPORT FORUM}

The International Transport Forum at the OECD is an intergovernmental organisation with 54 member countries. It acts as a strategic think-tank, with the objective of helping shape the transport policy agenda on a global level and ensuring that it contributes to economic growth, environmental protection, social inclusion and the preservation of human life and well-being. The International Transport Forum organises an annual summit of Ministers along with leading representatives from industry, civil society and academia.

The International Transport Forum was created under a Declaration issued by the Council of Ministers of the ECMT (European Conference of Ministers of Transport) at its Ministerial Session in May 2006 under the legal authority of the Protocol of the ECMT, signed in Brussels on 17 October 1953, and legal instruments of the OECD.

The Members of the Forum are: Albania, Armenia, Australia, Austria, Azerbaijan, Belarus, Belgium, Bosnia and Herzegovina, Bulgaria, Canada, Chile, People's Republic of China, Croatia, Czech Republic, Denmark, Estonia, Finland, France, Former Yugoslav Republic of Macedonia, Georgia, Germany, Greece, Hungary, Iceland, India, Ireland, Italy, Japan, Korea, Latvia, Liechtenstein, Lithuania, Luxembourg, Malta, Mexico, Republic of Moldova, Montenegro, the Netherlands, New Zealand, Norway, Poland, Portugal, Romania, Russian Federation, Serbia, Slovak Republic, Slovenia, Spain, Sweden, Switzerland, Turkey, Ukraine, United Kingdom and United States.

The International Transport Forum's Research Centre gathers statistics and conducts co-operative research programmes addressing all modes of transport. Its findings are widely disseminated and support policymaking in Member countries as well as contributing to the annual summit.

\section{Discussion Papers}

The International Transport Forum's Discussion Paper Series makes economic research, commissioned or carried out at its Research Centre, available to researchers and practitioners. The aim is to contribute to the understanding of the transport sector and to provide inputs to transport policy design.

ITF Discussion Papers should not be reported as representing the official views of the ITF or of its member countries. The opinions expressed and arguments employed are those of the authors.

Discussion Papers describe preliminary results or research in progress by the author(s) and are published to stimulate discussion on a broad range of issues on which the ITF works. Comments on Discussion Papers are welcomed, and may be sent to: International Transport Forum/OECD, 2 rue André-Pascal, 75775 Paris Cedex 16, France.

For further information on the Discussion Papers and other JTRC activities, please email: itf.contact@oecd.org

The Discussion Papers can be downloaded from: www.internationaltransportforum.org/jtrc/DiscussionPapers/jtrcpapers.html

The International Transport Forum's website is at: www.internationaltransportforum.org

This document and any map included herein are without prejudice to the status of or sovereignty over any territory, to the delimitation of international frontiers and boundaries and to the name of any territory, city or area. 


\begin{abstract}
Public-private partnerships (P3s) typically rely on long-term contracts between participants. When conditions arise that fall outside the expectations embodied in the contract, one party may seek to renegotiate the contract terms. Globally, the frequency of P3 contract renegotiations has been sufficient to raise questions regarding why these events occur and what their consequences are for the projects and society. The literature highlights four relevant causes behind renegotiation occurrences: unexpected exogenous changes, the complexity of the contractual relationship, winner's curse and rent seeking behavior. This study examines the US experience with highway P3 renegotiations, including four types of event: contract modifications, defaults, bankruptcies and buyouts. While the US highway P3 market has grown gradually, failure to understand renegotiations and their potential consequences may dampen the market and adversely affect national infrastructure investment efforts. The analysis finds that insufficient evidence exists to disentangle the drivers of renegotiation in the US, although exogenous changes and contractual relationship complexity appear to be paramount. The analysis highlights the distinct political and institutional environment that shapes highway P3 renegotiations in the US, suggesting the need for continuing and sensible analysis to effectively manage the undesirable consequences of renegotiations.
\end{abstract}




\section{Table of Contents}

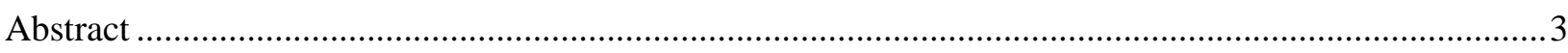

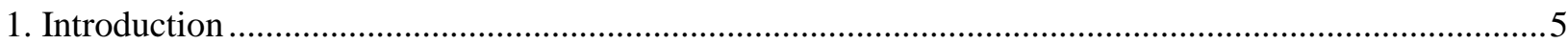

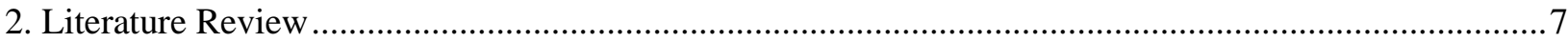

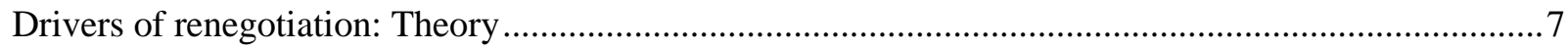

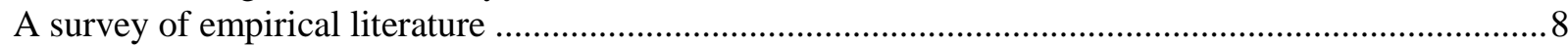

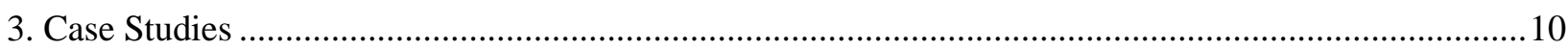

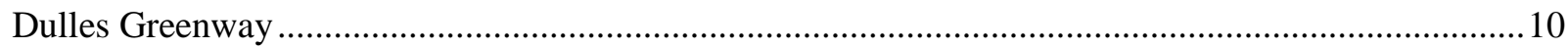

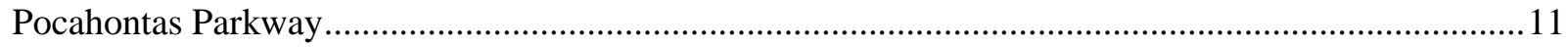

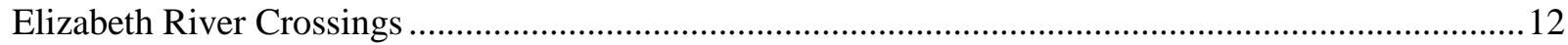

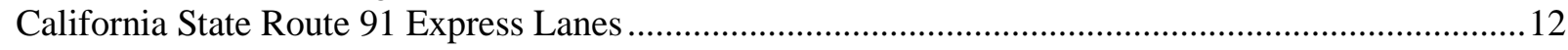

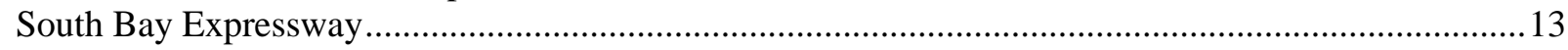

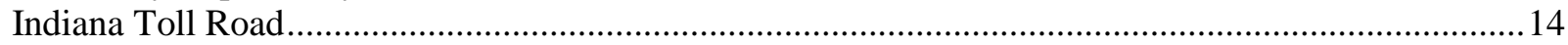

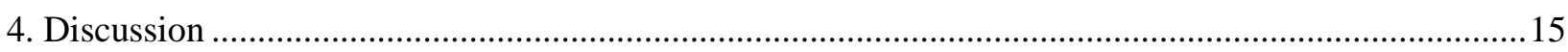

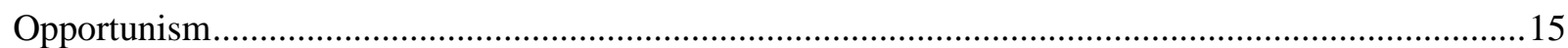

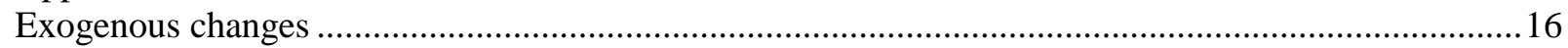

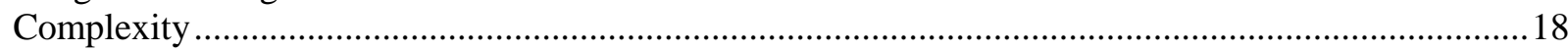

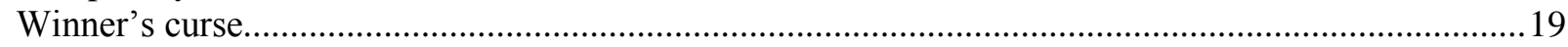

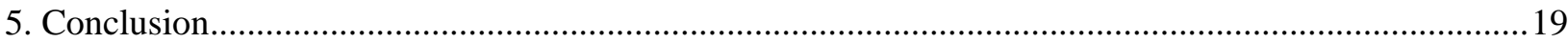

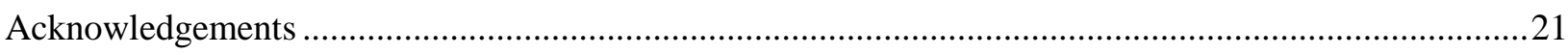

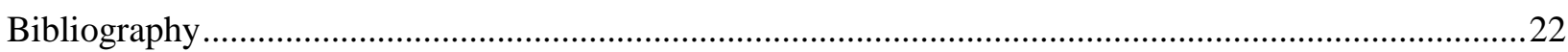

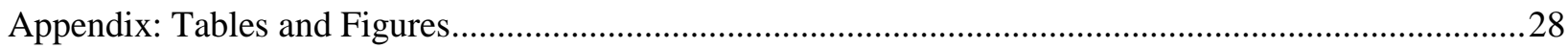




\section{Introduction}

Contract renegotiation allows contract participants to accommodate changes brought on by unexpected state changes not accounted for in original (incomplete) and often long-term contract relationships (Hart and Moore 1988). While parties to a contract might desire agreements that account for every contingency and preclude future renegotiations, such contracts would be prohibitively expensive to develop. As a result, compromises are required. However, this often enables contract parties to behave opportunistically with asset specificity, necessitating sometimes costly renegotiations of earlier contractual agreements (Klein, Crawford, and Alchian 1978; Williamson 1996).

This study focuses on contract renegotiation within the US highway public-private partnership (P3) market. Contract renegotiation is common in the private sector, especially in finance (Roberts and Sufi 2009) and labor contracts facing unexpectedly high inflation (Rich and Tracy 2013). Considering infrastructure P3s' long-term nature, inherent uncertainty, and need for sophisticated expertise, one may expect contract renegotiations to form an important component of the P3 contract process (Saussier, Staropoli, and Yvrande-Billon 2009). However, a number of unique complexities arise when contractual renegotiations involve the public sector. In addition, when renegotiation possibilities emerge in the infrastructure P3 context, public perceptions can be very negative. Observers may suspect that such renegotiations result from poor planning or opportunistic behavior by parties seeking rent at the cost of users and taxpayers. All these factors make P3 contract renegotiations a fruitful topic for research.

In addition, a deeper understanding of P3s may provide particular assistance for policymakers, especially in the transportation sector. Alternative procurement mechanisms for transportation infrastructure investment have experienced growing interest in the US (US Department of the Treasury 2014), and P3s in particular have become increasingly popular as severe budgetary and financial constraints drive governments to employ project equity and debt to access private sector funding and financing (Engel, Fischer, and Galetovic 2006; Small 2010). Figure 1 shows the growing trend in US P3s reaching financial closure each year between 1986 and 2013, across four infrastructure sectors. The number of deals closing annually increased rapidly during the mid-1990s and has fluctuated since then. The transportation sector in particular included increasing numbers of projects during this period, especially since 2010, despite some dips in the 2000s. In total, 512 P3 projects reached financial closure across all four sectors by the end of 2013. While the number of US transportation-sector P3s remains relatively small compared to other world regions, the highway and tolled highway subsectors have provided the largest proportion of $\mathrm{P} 3 \mathrm{~s}$ in recent years.

Despite P3s' growing popularity, an inadequate understanding of what drives renegotiation may affect the approach's future viability. Several notable US highway P3 renegotiation and bankruptcy cases have received wide attention, and analyzing why these occurred, and drawing policy conclusions, may inform future P3 implementation. The existing literature focuses on Latin American and European experience with P3 contract renegotiations, but it lacks an adequate analysis of the US context. Knowledge of foreign market experiences is valuable, but the US P3 market's unique characteristics, like its combination of common law, a federal system of government and its bankruptcy law, may have practical implications for how economic institutions evolve and how renegotiations proceed (Beck, Demirgüç-Kunt, and Levine 2003; Katsivela 2007; La Porta, Lopez-deSilanes, and Shleifer 2008; Qian and Weingast 1997, Cirmizi, Klapper and Utamchandani, 2012).

As a result, this study explores the US P3 renegotiation experience by addressing the following research questions: (1) How has the US experienced highway P3 renegotiations? (2) Does the US market demonstrate any distinct characteristics with regard to the drivers of renegotiation? 
While the term "P3" may refer to a variety of contracts between public agencies and private firms, our interests reflect the Organisation for Economic Cooperation and Development's (OECD) definition:

\begin{abstract}
"an agreement between the government and one or more private partners (which may include the operators and the financiers) according to which the private partners deliver the service in such a manner that the service delivery objectives of the government are aligned with the profit objectives of the private partners and where the effectiveness of the alignment depends on a sufficient transfer of risk to the private partners (ITF 2008)."
\end{abstract}

In the context of this study, we employ the term "P3" when referring to infrastructure projects and facilities delivered through arrangements where private firms partner with a public agency in delivering and providing a service, including Design-Build-Finance (DBF), Design-Build-Operate-Maintain (DBOM) and Design-BuildFinance-Operate-Maintain (DBFOM), but not Design-Build (DB).

Turning next to renegotiation, the theoretical literature often defines the term broadly to include any modifications to P3 concession contracts (Guasch 2004; Guasch, Laffont, and Straub 2008). The empirical literature, in contrast, tends to consider only major revisions to contractual agreements that the original contracts did not account for (Guasch, Laffont, and Straub 2008). Given this study's case study approach, we require a more broad definition to help us understand the nuances of the US P3 market. Consequently, in this paper we will analyze under the definition of renegotiation, the following events: contract modification, defaults, bankruptcies and buyouts (RDBBs). We define P3 contract modification to include modifications to P3 contractual agreements involving associated legal processes. Defaults occur when the private partner fails to meet the debt service requirements. Bankruptcies occur when the corresponding legal process is used for an illiquid or insolvent firm to pay its debts. Buy-outs of the private consortium occur when the new owners buy the P3 project. We believe our definition does not substantially alter the literature's conventional view, although we acknowledge that our perspective is motivated primarily by historical events in the US P3 market ${ }^{1}$.

Due to the small the number of P3 renegotiation cases in the US highway sector -- see Figure 2 where we accounted for 18 projects -- we explore the research questions through a series of case studies. Ultimately, the analysis highlights several unique characteristics of the US P3 market. First, the 2008 financial crisis acted as an external shock to a number of US highway P3s, directly and indirectly affecting demand for these facilities. Second, contractual complexities may explain why some P3 projects, particularly early ones, underwent renegotiations. Third, partner inexperience, both public and private, as well as underdeveloped institutional environments, influenced several cases. Overall, we find that the factors driving P3 contract renegotiations are very complex. Attributing a renegotiation case to any single factor or cause would be naive. Furthermore, empirically validating several theoretical explanations proved difficult (e.g. opportunism and the "winner's curse" effect). Often, only circumstantial evidence is available. To conclude, we suggest some directions for further analysis.

1 We provide two examples. First, the US has a very active tax-exempt municipal bond market which makes buy-out a relevant event to take into consideration. In the case of a negative, exogenous shock, a contract modification may be avoided if a new private partner is willing to take a higher risk or is willing to introduce new management that may be able to manage the impact of the shock. This would be a renegotiation in the sense that the private partner's asset ownership has changed. Second, the US has a different legal framework in terms of bankruptcy procedures. While in the US the bankruptcy framework primarily serves to protect the debtors, aiming to help companies survive liquidity events, in the EU the institutional framework is more lender-friendly (Cirmizi, Klapper and Utamchandani, 2012). The former favors the debtor to keep control of the company during the bankruptcy event and even allows the debtor to acquire additional debt to restructure the company. The latter focuses on paying back the debtor as soon as possible, implying an emphasis on quick liquidation of the company. This difference has practical implications in the highway P3 market, as pointed out recently by a leader in the US market (Nicolás Rubio, US President, Cintra, personal communication, November 20, 2014). 
The remainder of the paper develops as follows. The next section summarizes the theoretical and empirical literature regarding P3 renegotiation, and the following section presents six case studies. The final section discusses the case study findings and offers concluding remarks.

\section{Literature Review}

\section{Drivers of renegotiation: Theory}

Renegotiations can occur for several reasons. Economists, for example, have focused on the inherent incompleteness of P3s' contractual agreements (Guasch 2004). Given infrastructure projects' complexity and uncertain environments, contracts between public agencies and private partners cannot account for every contingency. As a result, incomplete contracts may cause renegotiations due to both strategic and non-strategic factors.

The perception that renegotiations produce negative consequences for the public arises from literature focused on opportunistic behavior by the private and the public sectors (Guasch 2004). For instance, P3 actors might pursue contract renegotiation as a strategic or opportunistic response to rent extraction opportunities, even at the expense of other parties in the deal. Both, government and private actors can behave opportunistically, against each other or against the public. In the government case, incumbent politicians might use P3s as an off-balance sheet mechanism to increase debt for infrastructure (Engel, Fischer, and Galetovic 2001; Engel, Fischer, and Galetovic 2009), expecting increases in infrastructure investment to produce favorable political outcomes.

Alternatively, private partners might behave opportunistically by winning P3 contracts with low offers, only to hold up the government later by asking for higher compensation via renegotiations (Guasch 2004). Given the often-prohibitive financial and political costs associated with soliciting new firms, the sponsoring public agency, at a disadvantage, may succumb, agreeing to change the terms as demanded.

The Mexican highway case offers a well-known example of such bidder opportunism. The Mexican Government granted 52 highway projects to private contractors during the 1990s, but many bids employed extremely optimistic forecasts. As a result, the government was forced to refinance the highways in 1997 at the cost of $\$ 3.3$ billion. $^{2}$

Public and private partners involved in a P3 project may also pursue contract renegotiation in order to defend themselves against potentially negative outcomes. The literature suggests three causes of non-strategic renegotiation: a) exogenous changes; b) inadequate preparation for complex contractual relationships; and c) ruinous agreements generated by excessive competition during the bidding process (known as the "winner's curse").

In the first case, renegotiations can help adapt the original contracts to current environment when unexpected exogenous events like macroeconomic shocks occur (De Brux 2010; Guasch, Laffont, and Straub 2008). Abrupt fluctuations in supply prices, interest rates, or regional economic activity can profoundly affect a P3 project's financial performance. In these instances, the project's financial equilibrium changes without inducement by either the public agencies or the private firms. Similarly, before using force majeure clauses after events like earthquakes, storms, or riots, the parties may try to maintain the relationship through renegotiations.

\footnotetext{
${ }^{2}$ All references are in nominal US dollars unless otherwise indicated.
} 
The financial crisis in 2008, for example, likely triggered a number of US highway P3 renegotiations. Such shocks can have direct effects given the close association between macroeconomic output and travel demand. Intuitively, a highway project's travel demand decreases during a recession, lowering the facility's revenue. In addition, the 2008 financial crisis' impacts in the housing sector undermined travel demand. Several highway P3s appeared financially viable given assumptions regarding increasing regional demand. During the crisis however, many development projects stalled, lowering demand for transportation facilities. Looking internationally, Guasch and co-authors highlight the 2001 Argentinean currency devaluation and Brazil's similar experience in 1999 (Guasch, Laffont and Straub, 2003). The authors suggest that uncertainty surrounding such events and the lack of guiding principles for readjustment introduce regulatory risk for P3 projects.

The second case involves situations with very complicated contract development, especially when adequate bureaucratic capabilities are lacking (Saussier, Staropoli, and Yvrande-Billon 2009). For example, public agencies may authorize P3 executions without adequate project management, legal, and/or financial staff. The private sector might also lack adequate staff or P3 experience. Confusion often emerges under these circumstances, motivating either or both partners to consider renegotiation. Which party initiates the process depends on which party the ambiguity favors.

The third case, referred to as the winner's curse, develops when bidding processes produce ruinous agreements. This situation may occur, for instance, when a public agency puts an existing toll road concession out for bid. The winner would make a financial arrangement to pay the government upfront to operate and maintain the facility for a pre-determined period. Subsequent toll revenues would cover the debt obligation as well as the facility's operation and maintenance costs. Since the facility's physical condition and future demand are often unknown, firms submit bids based on limited information with respect to the asset's true value. Auction processes favor the highest bids, potentially selecting a firm who overestimated the asset value. In such cases, unexpectedly low profits or even losses may result. After executing the contract, the winner may discover the concession's financial unsustainability and may request a contract renegotiation to continue operating the facility (Thaler 1988) ${ }^{3}$.

\section{A survey of empirical literature}

While the literature lacks a clear-cut test to determine why any particular renegotiation takes place, several empirical studies have investigated P3 renegotiations outside the US Although far from comprehensive, this section reviews some of the findings.

A number of studies have summarized statistics pertaining to P3 renegotiations in the Latin American transportation sector. An analysis of 218 Latin American transport concessions between 1989 and 2000 showed that $45 \%$ of the concessions underwent a renegotiation process. Fifty percent of these were initiated by the private partners (Guasch, Laffont, and Straub 2008). Similarly, an earlier study of the Latin America and Caribbean region from 1985 to 2000 found that $55 \%$ of transportation concessions faced renegotiation, compared to $9.7 \%$ for electricity concessions and $74 \%$ for water and sanitation (Guasch 2004). The study also found that on average across all sectors, renegotiation occurred two years after the contract award. In the transportation sector however, renegotiation occurred after three years on average, usually during the construction process, an unexpected result that usually is linked to private opportunism, as the private partner has the upper hand and the public sector may not be able to find an adequate substitute company to take over the project. In addition, renegotiation occurred more frequently after competitive bidding (46\% of concessions) than after bilateral negotiations (8\%), offering some support for the winner's curse theory. Renegotiations were also more prevalent under lowest tariff award criteria $(60 \%)$ and under requirements for private partner investment in the contract's

3 Another potential explanation was discussed during the ITF Roundtable where a draft of this research was presented. Renegotiations may be Pareto-enhancing to all the parties involved. This could happen with an unexpected high tax collection that is used to lower toll rates, permanently or temporarily. 
underlying asset (70\%) and occurred more frequently under price caps $(83 \%)$, probably because they made the private sector more vulnerable to external shocks. Table 1 summarizes additional findings.

Guasch and co-authors developed a model for contract renegotiations initiated by private contractors, empirically estimating factors associated with 307 P3 renegotiations in five Latin American countries' transportation and water sectors (Guasch, Laffont, and Straub 2008). The authors found that having an established P3 regulatory environment reduced the probability that a P3 project would undergo renegotiations. The regulatory framework helped prevent mistakes, decreased the risk of disruptive modifications to contractual agreements, and provided a means for both partners to address contingencies. The authors also found an association between price cap provisions ${ }^{4}$ and higher renegotiation probabilities; the greater risk to private partners under price caps increased agreement fragility. Private investment was also associated with significantly higher renegotiation probabilities, as were minimum revenue guarantees introduced to protect private partners. The authors argue that revenue guarantees lower efficiency incentives while raising incentives for strategically aggressive bidding. In addition, the authors found that most of the statistically significant variables, namely regulator existence, price cap regulation, concession duration, elections, economic growth, etc., generated the same directional effects for both government-initiated and firm-initiated renegotiations.

As regards government-initiated P3 renegotiations, the literature has also found links between institutional instability and politically motivated renegotiations initiated by public agencies to extract rent from private firms (De Brux 2010). Guasch et al. discuss a "typical" case where a newly elected political authority, seeking voter approval, unilaterally decides either to dishonor the initial contract's toll increases or to lower existing tolls (Guasch, Laffont, and Straub 2006). The authors formalize such renegotiations, finding that contract designs, inadequate regulatory frameworks, deficient institutional environments, and external shocks all increase the probability of government-initiated concession renegotiations. These findings support the public sector opportunism and the exogenous shocks and complexity arguments. The authors argue that these factors have distinct effects for public agency-initiated renegotiations compared to renegotiations initiated by private partners. In contrast, private financing and investment requirements decreased the likelihood of government-initiated renegotiations, but increased the likelihood of renegotiations initiated by private partners. Higher corruption levels, conversely, increased government-initiated renegotiations while decreasing renegotiations led by private partners.

The literature also finds institutional effects for private partner opportunism. Athias and Nuñez empirically investigated 49 toll road concessions around the world, focusing on the relationship between competition levels during initial bidding and renegotiation likelihoods (Athias and Nuñez 2009). Analyzing differences between original traffic forecasts, as included in winning bids, and actual traffic levels, the authors find an association between higher numbers of bidders in toll road concession auctions (more competition) and aggressive bids. This finding supports the winner's curse explanation for renegotiation. The analysis shows a stronger effect when public procuring agencies withhold their traffic forecasts when soliciting bids. The authors also demonstrate a stronger winner's curse effect when the public agency has limited experience with P3s (civil law countries or countries lacking stable institutions) $)^{5}$. In other words, bidders behave strategically and the winner's curse effect is stronger when renegotiations are easier.

4. Price-capping refers to a regulation developed "to squeeze out inefficiencies (...) by forcing transport industries to provide their services at increasingly lower real prices" (Button 2010, 470).

5 According to the authors, renegotiation is easier in civil law countries because legislation is the primary source of law. The court system must ponder and evaluate different codes, many of which may contain contradictory principles. In contrast, legal cases provide the primary source of law in common law countries, so contradictory statutes are less common (Athias and Nuñez 2009, 18-19). 


\section{Case Studies}

Table 2 shows the geographic dispersion of highway P3 projects with financial close in the US (45) and those that have had renegotiations (17). Out of these 17 projects, 7 had contract modification, 6 defaulted, 5 went bankrupt and 12 were bought up. We examine the renegotiation experiences of six US highway P3s, or a third of the total to date. The six cases are: Dulles Greenway (Virginia), Pocahontas Parkway (Virginia), Elizabeth River Crossings (ERC, also known as Midtown and Downtown Tunnels, Virginia), State Route 91 Express Lanes (SR91, California), South Bay Expressway (SBX, California), and Indiana Toll Road (Indiana). We selected these cases to encompass the diversity of US experiences with P3 highway renegotiations, especially across different geographies and years. We are including two cases from the West coast, one from the Midwest and three from the East coast. While the two cases from California originate from efforts done at the end of the 1980s, one of the Virginia cases, ERC, had its financial close in 2012. We included three cases from Virginia to understand the evolution of a state that is particularly active in the P3 market and plans to pursue this further ${ }^{6}$.

As shown in Tables 3 and 4 the six projects were developed in the two decades between 1993 and 2012 and they vary across several metrics: design characteristics, road length, road opening date, and the time of financial closure. Newly constructed roadway lengths range from relatively minor new construction (the Indiana Toll Road was a brownfield project) to 14 miles $(22.5 \mathrm{~km}$, Dulles Greenway). Some projects, like the Otay River Bridge (SBX) and the new Midtown Tunnel (ERC), include sophisticated technical designs. Others do not. The following sections briefly describe each case in turn, with an emphasis on renegotiations.

\section{Dulles Greenway}

The Dulles Greenway is located in Loudoun County, Virginia and covers 14 miles $(22.5 \mathrm{~km})$ connecting the Washington Dulles International Airport with Leesburg. As Virginia's first modern toll road, it was built in 1993 and opened in 1995 using the state's Highway Corporation Act of 1988. The project began with an unsolicited proposal from the Toll Road Corporation of Virginia (TRCV) that convinced legislators that approving the act would provide private funds for unfunded infrastructure projects (Wang 2010).

The project's original construction cost estimate came to \$350 million, and the Toll Road Investors Partnership II, L.P. (TRIP II), owned by the Shenandoah Group, Autostrade International, and Kellogg Brown \& Root, provided $\$ 40$ million in equity. The remaining funding derived from private debt involving CIGNA Investments, Prudential Power Funding Associates, John Hancock Mutual Life Insurance Company, Barclays, NationsBank, and Deutsche Bank AG (FHWA 2014a). The project was financed purely by the private sector and the TRCV even acquired most of its right of way without using condemnation through eminent domain. After 42.5 years, facility ownership would revert to the Commonwealth of Virginia.

The initial contract closed in 1993, but after the facility opened in 1995, traffic volumes were lower than expected. Revenues during the first years amounted to only 20 to $35 \%$ of initial expectations. TRIP II then sought to increase facility usage, including a toll reduction during the first year of operation that required approval from the state. Revenue did not grow to financially sustainable levels, and the project went into default the next year. In 1997, the partners increased toll rates and raised the speed limit to 65 miles per hour $(104.5 \mathrm{~km} / \mathrm{h})$. Two years later, the project restructured its debt and reached an agreement to increase the number 
of lanes from four to six. In 2001, TRIP II obtained a 20-year concession extension (to 2056) and three years later, they introduced variable toll rates adjusted for distance and time of the day.

In 2005, Macquarie Infrastructure Group (now Macquarie Atlas Roads) bought TRIP II, with 50\% of it eventually purchased by Macquarie Infrastructure Partners (Macquarie Atlas Roads 2009). In 2013, Virginia granted TRIP II the right to increase tolls annually by one percentage point above the consumer price index (Samuel 2008). That same year, and following California's South Bay Expressway experience (see below), an effort commenced to have the Commonwealth of Virginia "buy back" the toll road to lower the toll rates (Tanner 2013).

\section{Pocahontas Parkway}

The Public-Private Transportation Act (PPTA) of 1995 increased the flexibility provided by the Highway Corporation Act of 1988. It allowed Virginia to evaluate unsolicited proposals from private entities and employ financing tools like tax-free bonds (Commonwealth of Virginia 2012). Fluor Daniel and Morrison Knudsen (FD/MK) submitted a proposal to VDOT seeking a P3 agreement to design and build State Route 895, also known as Pocahontas Parkway. The road had been planned and approved by VDOT since 1983, but no funds were available for construction (Wang 2010). The Pocahontas Parkway Association (PPA) formed as a nonprofit 63-20 corporation to raise tax-exempt revenue bonds to finance the project's $\$ 354$ million construction cost. ${ }^{7}$ The remaining financing consisted of an \$18 million State Infrastructure Bank loan and \$9 million in federal funding for roadway design (FHWA 2014c). FD/MK provided an additional $\$ 5$ million in equity. The agreement included a four-lane toll road with an 8.8 -mile $(14 \mathrm{~km})$ extension, including a 0.3 -mile $(500 \mathrm{~m})$ bridge connecting Chesterfield and Henrico south to Richmond. When the facility opened to traffic in 2002, revenue came to $45 \%$ of expectations (USGAO (US Government Accountability Office) 2004, 51).

In 2006, facing a PPA default, VDOT received an unsolicited proposal from Transurban LLC regarding the project (Samuel 2006). As a result, the contract \} with FD/MK was terminated and a new agreement was signed with Transurban LLC. The new agreement included rights to enhance, manage, operate, maintain, and collect tolls from the roadway for 99 years. However, the agreement also included an obligation to construct the 1.85 mile $(3 \mathrm{~km})$ Richmond Airport Connector (RAC), with the expectation that the extension would increase demand for the Parkway. The agreement's financial structure included $\$ 141$ million in private equity, $\$ 55$ million in subordinated debt, a $\$ 150$ million Transportation Infrastructure Finance and Innovation Act (TIFIA) loan, and \$420 million in bank debt (FHWA 2014c). Three banks participated in the deal: Depfa Bank, Banco Espirito Santo de Investimento, and Bayerische Hypo- und Vereinsbank.

After 2009, facility usage diminished due to toll increases and declining regional travel demand after the 2008 financial crisis. Even the airport connector's completion did not increase demand enough to cover debt service. In 2012, Transurban completely wrote off its project equity of and planned to turn the toll facility over to its lender before becoming insolvent (Samuel 2013). In May 2014, DBi Services, a private company, took control of the road (Martz 2014).

7 In the US, public agencies may issue tax-exempt municipal bonds, enabling more cost-effective financing of public projects. Under the Internal Revenue Service Rule 63-20 and Revenue Proclamation 82-26, nonprofit public benefit corporations ("63-20 corporations") are also allowed to issue tax-exempt bonds. As a result, groups can establish 63-20 corporations that then form concession agreements with private firms to deliver, for instance, design-build-operate-maintain stages of an infrastructure facility. While the private partner usually arranges financing, the 63-20 corporation issues the debt (FHWA 2014b). 


\section{Elizabeth River Crossings}

Using the PPTA legal framework for unsolicited projects, VDOT approved an agreement with Elizabeth River Crossings OPCO, LLC (ERC) to design build, finance, operate, and maintain (DBFOM) the Downtown Tunnel/Midtown Tunnel/MLK Extension, also named the Elizabeth River Crossings project. The project will increase the connection capacity between Norfolk and Portsmouth and includes a) a new two-lane tunnel next to the existing Midtown Tunnel, b) improvements to the Downtown Tunnel, and c) improvements to a 0.8-mile $(1.3 \mathrm{~km})$ stretch of US Route 58. Construction began in 2012 with a concession length of 58 years and cost estimates of $\$ 2.1$ billion, not including costs related to renegotiations. ERC, a joint venture of Skanska Infrastructure Development and the Macquarie Group, invested $\$ 272$ million in project equity. Additional funding derived from a $\$ 465$ million TIFIA loan, $\$ 408$ million in public funds, $\$ 675$ million in private activity bonds, and \$268 million in toll revenue from the existing tunnels (FHWA 2014d).

The project underwent a public-sector-initiated renegotiation in 2012 to delay tolling in exchange for a government payment of $\$ 100$ million (Samuel 2012). Then, in 2014 when tolls were set to begin, a new governor renegotiated the contract terms to lower tolls during the first revenue-generating years. The renegotiation cut toll rates in exchange for $\$ 82.5$ million (Office of Governor 2014). Toll collection at the new rates commenced February 1, 2014. The public had severely objected to the original plan involving tolls on the existing tunnels in advance of the project's completion. Opponents claimed that such tolls were effectively taxes rather than user fees since users saw no viable free alternative (Reinhardt, W. G 2012). Danny Meeks, a resident of Portsmouth, filed a lawsuit contending that VDOT unlawfully imposed the toll charges. Eventually, the Supreme Court of Virginia ruled in VDOT's favor (Meeks v. Elizabeth River Crossings OPCO, LLC and Virginia Department of Transportation, 2013 VA App. 2013).

\section{California State Route 91 Express Lanes}

In the 1980s many believed that Southern California needed a billion dollar investment in its road infrastructure (RoadTraffic-Technology 2012). To address this need, the state enacted Assembly Bill No. 680 allowing P3 use in four demonstration projects (Giuliano et al. 2012). The four projects were selected through a competition organized by the State Department of Transportation, one of which included a project building express toll lanes in the existing State Route 91's median. ${ }^{8}$ In 1990, the state signed a build-transfer-operate (BTO) franchise agreement with the California Private Transportation Company (CPTC) as the private partner. The companies forming this entity included Level 3 Communications, Inc., Compagnie Financiere et Industrielle des Autoroutes (Cofiroute), and Granite Construction Inc. (Caltrans (California Department of Transportation, 2009). The private partner provided $\$ 20$ million in equity with additional funding coming from a $\$ 7$ million subordinated loan from the Orange County Transportation Authority (OCTA) and \$100 million in bank loans from Citicorp USA, Banque National de Paris, Societe Generale, Deutsche Bank and CIGNA Investments (FHWA 2014e).

The toll lanes opened in 1995, connecting Orange County to Riverside County through a four-lane, 10-mile $(16 \mathrm{~km})$ extension. The operation agreement was to last 35 years. In addition, it was the first US road to rely completely on electronic toll collection and congestion management pricing, that is, prices adjusted to traffic flow.

Given the growing transportation infrastructure needs in the area, the OCTA faced citizens' discontent regarding the lack of additional investment in transportation infrastructure. Of particular concern was the original franchise agreement's "non-compete" clause constraining Caltrans and OCTA's ability to add "competing" or "complementary" road capacity. First, OCTA attempted to abrogate the clause but was prevented from doing so in court, as it was attempting to overcome the non-compete clause by arguing, without support, that the

8 The criteria used by Caltrans included: the importance of the transportation need served, the ease of implementation, the experience of the consortium, the promotion of economic development and how innovative it was (Wang, 2010). 
additional infrastructure was to be built for safety reasons. Finally, the OCTA bought out CPTC in 2003 in order to reduce traffic congestion. As a result, OCTA issued \$195 million in toll revenue bonds (Metro ExpressLane 2014), purchasing the project for $\$ 207.5$ million.

\section{South Bay Expressway}

The South Bay Expressway (SBX), like the State Route 91 Express Lanes, grew out of Assembly Bill no. 680. The project was designed as a design-build-operate-transfer (DBOT) agreement lasting 35 years and covering a 9.4-mile (15km) extension connecting Spring Valley to Otay Mesa in southern San Diego County, California. The goal was to serve anticipated development generated by growing trade with Mexico (Wang 2010). The state signed an agreement in 1991 with California Transportation Ventures, Inc. (CTV), originally owned by Parsons Brinckerhoff, Egis Projects, Fluor Daniel and Prudential Bache, although the first two partners left after 1992. In 1997 Koch Industries bought $29 \%$ of the stock (Giuliano et al. 2012) and in 2002 CTV was bought completely by Macquarie Infrastructure Group.

The project experienced several delays. First, the private firm had agreed to manage the project's environmental permits. However, it did not obtain the requisite permits until 2001 despite the franchise agreement having been signed in 1991. Government environmental agencies including the US Fish and Wildlife Service, the Army Corps of Engineers, and the US Environmental Protection Agency imposed permit requirements including wetlands restoration, protected habitats for endangered species, and recreational improvements in nearby communities.

Second, Parsons Brinckerhoff decided to sell its stake to Macquarie Infrastructure Group in 2002 after the permitting delay. This change in the agreement allowed Macquarie to access public funds to offset costs associated with the construction delays and environmental permitting. This included $\$ 140$ million from the US Department of Transportation (USDOT) via the Transportation Infrastructure Finance and Innovation Act (TIFIA) (FHWA 2014f). Additional funding came from private equity ( $\$ 130$ million) and bank debt ( $\$ 400$ million) from Banco Bilbao Vizcaya Argentaria, Depfa Bank plc, Allied Irish, Bank of Ireland, BNP Paribas, Commonwealth Bank, DVB Bank, DZ Bank, and HSH Nordbank (Fretz 2010).

Third, design changes to reduce environmental impacts complicated the Otay River Bridge construction, requiring a "top-down" approach using precast segmental structures to build the 19-story bridge (Soule and Tassin 2007). Ultimately, the contract between CTV and the bridge constructor, Otay River Contractors (ORC), involved a schedule that could not be fulfilled (according to ORC) due to requirements by Caltrans, the City of Chula Vista and the County of San Diego. This eventually led to litigation. Ultimately, the bridge-related issues delayed the project's opening by over 15 months and raised the estimated cost from $\$ 400$ million in 1990 to $\$ 635$ million when the project opened in 2007.

In addition, the project opened just as the subprime mortgage crisis hit San Diego, reducing demand to about a third of expectations (Chapter 11. Case No. 10-04516-LA11. Declaration of Anthony G. Evans, Chief Financial Officer of South Bay Expressway, L.P., in support of the debtor's chapter 11 petitions and first day motions. 2010). This situation eventually led CTV to file for bankruptcy in March 2010. After a settlement between the creditors, the US Bankruptcy Court created the New SBX Equity owned by all the creditors (Samuel 2011). USDOT claims were reduced from $\$ 170$ million to $\$ 99$ million and the banks' claims were reduced from $\$ 361.4$ million to $\$ 210$ million. Finally, the San Diego Association of Governments (SANDAG) bought the New SBX Equity, paying the banks $\$ 247.5$ million in cash, and extinguishing the private sector participation in the project. Of the original $\$ 172$ million owed to USDOT (capital plus $\$ 32$ million in capitalized interest), the department will receive an estimated of $\$ 93$ million from toll revenues and will keep 32\% of the project ownership, sharing any of the operation's surpluses (Hawkins 2011; Jensen 2011; FHWA 2014f). Following its acquisition, SANDAG decreased toll rates by $40 \%$, decreasing revenues by $20 \%$ (Poythress 2012). 


\section{Indiana Toll Road}

The Indiana Toll Road (ITR) provides particularly valuable insights for policy debates regarding toll road P3s (Wee 2012). The project, originally named the Indiana East-West Toll Road, was funded by tolls through a legal framework established in 1951. The road opened in 1956 as part of the US Interstate Highway System, covering 156.28 miles $(251.5 \mathrm{~km})$ and connecting Chicago, Indiana, and Ohio. The Indiana Toll Road Commission managed the road until 1981, after which the road became part of the Department of Highways. In 1983, the newly created Indiana Toll Finance Authority, later the Indiana Transportation Finance Authority, took over the highway, giving it political and financial independence from the state (Levy 2011).

In 2006, under Governor Mitch Daniels, Indiana awarded the rights to maintain, operate, and collect tolls from the Indiana Toll Road to ITR Concession Co. LLC for the following 75 years. The ITR agreement included an operations and maintenance (O\&M) contract covering the 156-mile $(251 \mathrm{~km})$, four-lane highway, and the construction of additional lanes along 10 of those miles. Four companies submitted proposals and ITR Concession Co. LLC, a joint venture between Cintra Concesiones de Infraestructuras de Transporte (acquired by Ferovial in 2009) and Macquarie Atlas Roads, won the bid, offering to pay $\$ 3.8$ billion up front. The deal included \$748 million in equity and \$3,248 million in debt from Santander, Bankia, Dexia, The Royal Bank of Scotland plc, BNP Paribas, Banco Bilbao Vizcaya Argentaria and Depfa Bank (InfraDeals 2014). The deal allocated $\$ 255$ million to the seven counties adjacent to the toll road, $\$ 250$ million to the third-lane expansion, and \$40 million to introduce electronic toll collection. An additional \$150 million went to Indiana's 92 counties for road improvements (Gilroy and Aloyts 2013).

The deal raised much opposition arguing that the state would see short-term gains in exchange for private firms profiting at the expense of citizen welfare over the long term. However, the joint venture faced a $\$ 260$ million loss in 2010, with expectations for debt service default by 2012 (Holeywell 2011). The recession and gas prices offer possible explanations. Given growing debt service concerns in 2013 and 2014, the participants began renegotiations with their lenders. In March 2014, for example, the project partners sold $\$ 500$ million of their debt to investment firms "for around 60 cents on the dollar" (Glazer 2014).

In total, five renegotiations have occurred between the Indiana Toll Road's public and private actors (IFA 2013a). First, in exchange for state reimbursement (\$60 million), the private actors agreed to a "toll freeze" in 2006 until electronic tolling was in place. Second, that same year, the state agreed to an investment obligation reduction. Third, in 2007 the state agreed to delays on certain investments until 2010. Fourth, it agreed to reimbursements in 2008 due to lost revenue connected to the electronic tolling (\$60 million). Finally, in 2010 the state agreed to additional delays on certain investments until 2011. In September 2014, ITR Concession Co. LLC announced it would file for bankruptcy, as the project's interest rate swaps, a condition imposed by the lenders, worked against its financial position by increasing its debt by $\$ 2.15$ billion (Benman 2014). 


\section{Discussion}

The cases of P3 contractual renegotiations in the US in the previous section demonstrate the unique characteristics of the market distinct from other regions of the world. Table 5 summarizes our overall assessment of these cases and Table 6 which follows Guasch (2004) on Latin American concessions compares the consequences of the renegotiations. These cases can be categorized with respect to the sector that initiated the renegotiation process, while highlighting some of the consequences. Among the cases we analyzed, the public sector started the renegotiation process in two of the six cases. In the Elizabeth River Crossings case, toll deferral was the main interest; while in the State Route 91 Express Lanes case, the OCTA repurchased the concession to overcome the noncompete clause that was preventing the expansion of the general purpose lanes. In the other cases, the private sector initiated renegotiations. The Dulles Greenway case involved tariff changes, additional investments and the extension of the concession term. The Pocahontas Parkway project involved additional investments and extending the term of the concession. The Indiana Toll Road case resulted in a reduction of the investment obligations and compensation for toll freezes. The private partner changed in three of these four projects, while the Indiana Toll Road may undergo further changes, as the concessionaire filed for bankruptcy recently in September $2014 .^{9}$

In the absence of a clear test to determine the cause of each renegotiation in a robust manner from competing hypotheses, we will instead discuss circumstantial evidence that may provide insight for our analysis in the US. We focus on the four theoretical explanations discussed above - opportunism, exogenous changes, complexities and the winner's curse effect.

\section{Opportunism}

Determining opportunistic motives (Williamson, 1996) of one party or the other requires careful evaluation. In the case of the SR-91 Express Lanes project, the opportunism hypothesis sheds light on the interesting mix of claims on opportunistic behaviors of both the public and private partners (Vining, Boardman, and Poschmann 2005). On the one hand, the private party obtained substantial profits, \$29 million in just one year, which some may consider as substantial compared to the project's construction cost of $\$ 130$ million. The contractual agreement also included a non-compete clause, protecting the concession from possible competition with expanded general-purpose lanes. On the other hand, the government attempted to bypass the non-compete clause in expanding the capacity of generalpurpose lanes (citing safety reasons), but was eventually forced to settle in court. Furthermore, the government attempted to acquire the Express Lanes legislatively through condemnation. Therefore, one may find it difficult to reject opportunistic motives of the public sector more so than the private partner, although the final purchase agreement implicitly indicates satisfactory outcomes for both parties.

Elections have been considered to provide insights with respect to the public sector's opportunism (Guasch, Laffont, and Straub 2007). As already discussed above, changes in public leadership may trigger attempts to gain political

\footnotetext{
${ }^{9}$ South Bay Expressway here tariff decrease occurred after the local government took charge of the road.
} 
advantage, or to protect oneself from the accusation of gaining political advantage. ${ }^{10}$ Facing the threat of losing in upcoming elections, incumbents may resort to renegotiation of P3s for popular policies (e.g. lower tolls, add capacity for low public cost). An incoming public official may attempt similar policies for the same reason. We identify shifts in political party control since 1992 in one or more state government branches - governor and both legislative chambers, although we recognize that the executive branch is the primary decisionmaker with respect to P3 renegotiations.

As Table 7 shows, Indiana demonstrates the lowest contestability in its Senate (no party shifts) and governorship (one shift), but the highest contestability in its House of Representatives (four shifts). The renegotiation began under complete Republican Party control (2006) and lasted when Democrats took control of the State House (2007). No further renegotiation occurred since the Republicans recovered complete control in 2010, until the Indiana Toll Road filed for bankruptcy in 2014. We cannot conclude in this case that public opportunism motivated the renegotiation in Indiana.

Over the study period, California experienced no changes in its Senate's party control, two changes in its House, and three changes in its governorship. The state's purchase of State Route 91 took place in 2003, one year before Democrats lost the executive branch. Similarly, the significant South Bay Expressway renegotiation took place when the Democratic party controlled the governorship and both legislative houses, but the party had either just gained or was about to lose that control. This may favor the hypothesis of public opportunism but the evidence remains insufficient.

Virginia shows the highest political contestability across the governorship and both legislative chambers. The Pocahontas Parkway renegotiation coincided with changes in party control across all three bodies. Similarly, the Elizabeth River Crossings renegotiations took place as the Senate and the executive branch experienced changes in party control. Although one may argue from these cases that this state is more prone to renegotiations by public sector opportunism, in the absence of information regarding their motives, the evidence is insufficient.

It is difficult to detect private opportunism. However, we can show whether the companies behind the deal have faced other renegotiations (see Table 8). Previous renegotiation experiences might familiarize a company with renegotiation procedures, aiding them when complexity or exogenous shocks overwhelm subsequent projects. From this table, we see that, as of 2012, Macquarie, Fluor, Skanska Infrastructure Development, and Ferrovial all participated in highway $\mathrm{P} 3$ projects around the world that experienced renegotiation at some point. However, most companies active in the P3 industry are likely to have some experience with renegotiation. Further research is necessary to understand the implication of these measures ${ }^{11}$.

\section{Exogenous changes}

In the presence of exogenous shocks, renegotiations may help both parties accommodate unexpected changes. In the case of highway P3s, we need to consider macroeconomic risks as potentially significant exogenous changes. To evaluate whether exogenous changes drive US renegotiations, we investigate five macroeconomic variables found in

10 The former makes reference to the differences in the incentives faced by the roving and the stationary bandit (Olson 2000). The latter makes references to third-party opportunism and political contestability explored for public contracts (Moszoro and Spiller 2012).

11 The evidence of private sector renegotiation experience is inconclusive because not only the private companies have it; the lenders do also, as most of the banks involved in the highway P3 market in the US are foreigners. As lenders lose from private opportunism this would help diminish its occurrence. 
the literature: inflation rate, economic growth, unemployment rate, input prices, and interest rate (Guasch, Laffont, and Straub 2007).

To capture negative demand shocks we focus on changes in the inflation rate, economic growth, and the unemployment rate. First, we consider whether sudden increases in the inflation rate, measured through the Consumer Price Index (CPI), indicate negative real income shocks. If toll road usage presents positive incomeelasticity, then sudden increases in the inflation rate should decrease available income and the revenue generated by transportation P3s. Figure 3 shows no inflationary spike since 1992. In fact, the most significant shifts reflect the Great Recession's deflationary period spanning March 2009 through October 2009. This suggests that inflation shocks could not have triggered the case study renegotiations.

Second, declines in economic growth, measured through gross domestic product (GDP), may diminish the income available to spend on toll roads. Figure 4 shows that California and Virginia experienced negative growth in 2009. In addition, both states experienced almost zero growth between 2001 and 2002, potentially affecting the Dulles Greenway and South Bay Expressway renegotiations. Indiana, by contrast, experienced four years of negative growth (2001, 2005, 2008, and 2009). While these GDP declines were important in the state, the Indiana Toll Road's financial close (2006) and its renegotiations (2012 and 2014) do not coincide with these economic downturns. However, the recessions' effects may have persisted over several years despite rapid recoveries in economic growth. For example, the 2009 recession may not have immediately influenced the projects, but its effects may have rather accumulated in the following years, affecting government budgets and elevating unemployment. It appears that the evidence linking shocks to the economic growth to renegotiations is mixed.

Third, a surge in unemployment may also have decreased demand for toll roads. We include unemployment in addition to economic growth because unemployment rates can rise or remain high despite recovery to economic growth. Figure 5 shows the unemployment rate from January 1992 through April 2014. Unemployment showed a decreasing trend until the economic downturn of 2001, increasing by almost $2 \%$ in the states under analysis. Unemployment rates declined again starting in 2003, but with the exception of California, they did not reach their previous lows. Unemployment increased again with the recession, peaking between 2009 and 2010 before slowly declining. The persistently high unemployment rates seen after 2009 may help explain the demand risk-related renegotiations occurring after the recession (e.g., Pocahontas Parkway and South Bay Expressway).

A different perspective considers how changes to input prices and interest rates may have affected the supply of transportation infrastructure by altering project profitability. Using the Producer Price Index (PPI), we first consider two potential sources of cost increases: construction machinery manufacturing and iron and steel mills. Figure 6 shows PPI changes for both sources starting in 1992. Inflation for construction machinery manufacturing has remained constant under $10 \%$. Iron and steel mills' production costs however have shown much more volatility, particularly between 2002 and 2011. Cost changes during this period ranged from $45 \%$ inflation in November 2004 to $40 \%$ deflation in June 2009. These unexpected fluctuations in steel costs may have driven the South Bay Expressway's renegotiation.

Interest rate shifts may also have affected the project's perceived profitability. Partners may prefer to invest their money under variable market rates rather than in a P3 project. Figure 7 shows the bank prime loan rate from 1992 to 2014, noting how debt service increased 50\% between 1993 and 1994 and increased 100\% between 2003 and 2005. These high interest rates may have affected the Dulles Greenway renegotiations (1994 to 2000, 2005). The combination of financial practices and persistent market conditions may also affect P3 projects. In the case of the Indiana Toll Road, in 2007, banks conditioned their funds on the acquisition of an interest rate swap which would protect the project in case of raising interest rates. However, interest rates fell below the 2007 levels, instead of 
rising, as a consequence of the recession, which put the project under financial stress and eventually drove the project to bankruptcy in $2014^{12}$.

Considering this evidence, it appears that economic growth, unemployment rates, input prices, and interest rates may have had important effects on the renegotiation of the cases, although more robust analysis is necessary to be more conclusive.

\section{Complexity}

The political environment of $\mathrm{P} 3 \mathrm{~s}$ can also increase complexity that decision makers need to account for in reaching a deal or to respond when circumstances change, requiring renegotiation with the partner at any point through the project life. In the US, the politics of not only the P3s but also public infrastructure investment in general have experienced political backlash on the basis of civil rights, environmental protection, opposition to tolls, and so forth. Opposition to the rapid growth of the Interstate highway network nationwide during the 1960s to 1970s emerged in urban regions across the nation, significantly influencing the outcome of some of the planned facilities. For example, the Washington D.C. region once embraced the plan of a 38-mile interstate highway network. Many of the planned links were to pass through predominantly black neighborhoods. After 22 years of fierce political battles, only 10 miles were ever built, and the issue of race played a considerable role in shaping the limited highway network in the District of Columbia today (Levey and Levey 2000). As such, one may therefore argue that the civil rights issues have played an important role in the politics of highways at all levels in the US

Intuitively, toll charges on freeways would face equivalent political challenges, especially when a given toll scheme may be perceived to disproportionally affect particular neighborhoods. The Elizabeth River Crossings project predominantly serves cross-river commuters and businesses in port-related industries in Hampton Roads. It is in this context of the US politics that tolling free facilities resulted in persistent opposition, conceivably leading the public decision makers to delay the imposition of tolls and to lower the toll levels during the ramp up period (VDOT 2014). Resonating with the political dynamics of the Elizabeth River Crossings Project, the literature on ethnic, linguistic, and religious fractionalization and fragmentation of communities have suggested that population diversity may complicate implementation of public goods projects (Alesina, Baqir, and Easterly 1999; Alesina and La Ferrara 2000; Alesina, Glaeser, and Sacerdote 2001). We investigate the potential of public disagreement on particular policy or projects, through estimating an ethnic fractionalization index using census information from 2010 . Table 10 shows that fractionalization is the highest in California (0.77), high in Virginia (0.58), and relatively low in Indiana (0.37). ${ }^{13}$ When compared worldwide data as summarized in Table 11, California and Virginia show a high proportion of ethnic diversity. Accordingly, the renegotiation experiences of P3s in these states can be partially explained on this basis, although obviously more rigorous and across-the-board analysis would be necessary to draw conclusive insights in this regard.

Looking next at the public partners, we evaluate whether each state had previous experience with P3s. Governments with limited P3 experience may struggle to manage such innovative projects. Five of the case study projects were among the first in their state. Indiana Toll Road was the first P3 in Indiana, while the SR-91 Express Lanes project was the first in California. South Bay Expressway, despite its construction a decade after State Route 91, was part of

12 The interest rate swap is a financial instrument used for hedging the risk of rising interest rates. In the case of ITR, if the interest rates had increased, it would have been protected. However, as the interest rates decreased instead of increased, it put the project under stress.

13 The fractionalization index follows this formula: $F R A C T_{j}=1-\sum_{i=1}^{N} s_{i j}^{2}$, where $\mathrm{s}_{\mathrm{ij}}$ is the proportion that any particular racial group has in state j. This index follows the work by (Alesina et al. 2003). 
California's initial 1989 experiment under Assembly Bill No. 680. Dulles Greenway was Virginia’s first private toll road since the 1800s, a project constructed under the Highway Corporation Act of 1988 (VDOT 2006). Similarly, Pocahontas Parkway was the first project to take advantage of the state's Public-Private Transportation Act of 1995, and was the first 63-20 corporation for highways. As a result, government inexperience offers a possible explanation for these project's renegotiations, as governments had neither the appropriate expertise nor human resources with the experience to deal with some of the uncertainties in handling these agreements. The Elizabeth River Crossings project, however, cannot possibly be considered as novel. The financial close in 2012 and the state's two-decade experience with $\mathrm{P} 3 \mathrm{~s}$ prior to the deal indicate that inexperience of the state agency may not be able to explain this project's renegotiation.

Finally, states' institutional environment can also contribute to relational complexity of P3 deals. Even with decades of P3 experience, a firm or government may not have the technocratic capacity to manage a P3 contract. We review state management capacity using the State Management Report Card, funded by The Pew Charitable Trusts evaluating state performance, focusing our attention on the infrastructure component ${ }^{14}$ (summarized in Table 12 for 1999, 2005, and 2008) (Barrett and Greene 2008; Government Performance Project 2005; King, Zeckhauser, and Kim 2004). According to these ratings, Virginia demonstrates the strongest infrastructure performance during the analysis period. Indiana falls in the middle of the table, with California showing one of the lowest scores. In this regard, one would expect Virginia to have the strongest institutional quality of the states under consideration. The case results do not reflect this expectation, so government management capacity may not necessarily be a factor driving US P3 renegotiations.

In addition, since Guasch et al. find evidence that regulatory bodies diminish renegotiation probabilities in highly corrupt environments, we analyze whether state regulatory bodies oversee the P3 contract process (Guasch, Laffont, and Straub 2007). Virginia has the Office of Transportation Public-Private Partnership (OTP3) whose objective is to ensure the timely delivery of Public-Private Transportation Act (PPTA) projects addressing priority transportation needs. The OTP3 operates under the Secretary of Transportation, and while outside VDOT, it receives administrative support from the agency (Virginia Office of Transportation Public-Private Partnerships 2014 ). ${ }^{15}$ In addition, the multimodal PPTA Steering Committee reviews the OTP3 recommendations. In contrast, California and Indiana both rely on their Departments of Transportation to oversee their P3 projects (KPMG 2013). These institutional differences suggest that OTP3's independence and dedicated resources should reduce the number of negotiations in Virginia. The case results do not reflect this expectation, suggesting that the presence of dedicated regulatory agencies may not reduce renegotiation occurrences for these cases.

\section{Winner's Curse}

Finally, we discuss of the possibility that the winner's curse effect may have been in place in any of these cases. This effect, in the context of brownfield concessions, would take the form of unreasonably high bids, generating profit shortfalls that necessitate contract renegotiations (Athias and Nuñez 2009). In contrast, in the context of greenfield

\footnotetext{
${ }^{14}$ This component evaluates states based on five dimensions (Barrett and Greene 2008): a) The state regularly conducts a thorough analysis of its infrastructure needs and has a transparent process for selecting infrastructure projects; b) the state has an effective process for monitoring infrastructure projects throughout their design and construction; c) the state maintains its infrastructure according to generally recognized engineering practices; d) the state comprehensively manages its infrastructure; e) the state creates effective intergovernmental and interstate infrastructure coordination networks. The evaluation takes into consideration academics and journalists expert knowledge of the area and the states.

${ }^{15}$ In November 2014 the OPT3 changed its name to the Virginia Office of Public-Private Partnerships.
}

J. Gifford et al. — Discussion Paper 2014-16 — @ OECD/ITF 2014 
P3 projects, this effect would be reflected in unreasonably low bid, which would then require renegotiation to ensure construction completion and continuing operation by the private partner. To investigate whether this "winner's curse" effect influenced any of the study cases, we evaluate the award processes and the numbers of bidders involved. Only two of the case projects involved bidding processes: the Indiana Toll Road and Elizabeth River Crossings. The winning Indiana bid by Cintra Concesiones de Infraestructura de Transporte and Macquarie Atlas Roads offered $\$ 3.8$ billion up front. In contrast, Indiana Road Company LLC offered \$2.8 billion, Itinere Infraestructuras S.A. offered \$2.5 billion, and Indiana Toll Road Partners LLC offered \$1.9 billion (IFA 2013). Given that the competing bids were lower than the winning bid at least by $\$ 1.0$ billion, it is difficult to reject the claim that "winner" over-bid, leading to the renegotiations that the concession eventually underwent ${ }^{16}$.

In contrast, the Elizabeth River Crossings' renegotiations appear to be unrelated to the winner's curse. While three companies submitted statements of interest, only one pursued the project. As a result, a bilateral negotiation process between the public and private actors established the deal's final elements, including the price.

\section{Conclusion}

This paper investigated the US highway P3 market experience, focusing on contractual renegotiations. Beginning with a theoretical framework derived from a brief literature review, we conducted six case studies of tolled highway P3 renegotiations. These cases vary considerably with respect to their contract types, engineering characteristics, and political and economic circumstances. Moreover, in contrast to E.U. or Latin American markets, these US projects inhabit distinct, state-based institutional and regulatory environments. However, US P3 renegotiation has not experienced the same level of analysis as international markets. The relatively few US P3s and scarce data availability might explain this situation, while they present considerable difficulty in employing econometric analysis methods for addressing the research questions. This paper serves as a foundation to bridge this gap in the literature.

The six case studies presented in this paper raise a few distinct characteristics of the US highway P3 market. Regarding the renegotiations initiated by the private partners, we found that public agencies in the US have demonstrated their willingness to let their private partners default, go bankrupt, or be bought out when the facilities are performing poorly in terms of the usage. Notably, these events did not involve risking the public sector funds except in one case (South Bay Expressway and TIFIA). With respect to the renegotiations initiated by the public sector, we find that the changes to the P3 schemes have often been claimed to be beneficial for the society, when careful evaluation is actually necessary to make such claims. The critical issue that we find is the need for public education to promote sound understanding of how P3s work and what the implications of each renegotiation to the public may be.

Rather than jumping to conclusions, we need to recognize that the cases reviewed in this study demonstrate the effect of multiple factors in leading to unexpected contractual renegotiations. The existing body of literature provides poor

\footnotetext{
${ }^{16}$ During the ITF Roundtable where a draft of this research was presented it was argued that this behavior could also be interpret as "aggressive bidding" a form of private opportunism, where a company bids to obtain the contract, hoping to obtain better conditions afterwards, via renegotiations. In that regard, SBX had not occurred, so there was not a highly publicized highway P3 bankruptcy case showing that the U.S. public sector would behave differently than that of Latin America.
} 
guidelines to disentangle the complexity behind each renegotiation case and to be able investigate the effect of one hypothesis from another. Therefore, the analysis in this study highlights the need for scholars to continue developing analytical frameworks by which such insight can be effectively drawn from the experiences. It is equally important to emphasize the need for policy makers to ensure reasonable degree to disclose P3s' information to allow these analyses.

The US infrastructure P3 market is relatively new and still growing. The experience of P3 renegotiations may be a reflection of the learning curve that the policy makers are climbing before a robust market with reasonable returns to both public and private partners emerges. One may find in the literature a number of proposals to manage undesirable consequences of P3 renegotiations (e.g., Engel, Fischer, and Galetovic 2006). Yet, the analysis in this study points to the need for continuing evaluation of managing P3s and their renegotiations, in a manner that is sensitive the unique characteristics of US

\section{Acknowledgements}

The research and writing of this paper was supported in part by the International Transport Forum and the George Mason University Center for Transportation Public-Private Partnership Policy. The Center receives support from the Office of Transportation Public-Private Partnerships of the Commonwealth of Virginia. Porter Wheeler provided insightful comments. Morghan Transue substantially edited the manuscript and Susan Woods provided invaluable administrative support. The authors would like to express their gratitude to the valuable comments from the participants of the ITF Roundtable. This paper represents the views of the authors, who are responsible for any errors or omissions. 


\section{Bibliography}

Alesina, A., R. Baqir, and W. Easterly. 1999. "Public Goods and Ethnic Divisions.” The Quarterly Journal of Economics 114 (4): 1243-84.

Alesina, A, A Devleeschauwer, W Easterly, S Kurlat, and R Wacziarg. 2003. "Fractionalization.” Journal of Economic Growth 8 (2): 155-94.

Alesina, A., E. Glaeser, and B. Sacerdote. 2001. Why Doesn't the US Have a European-Style Welfare System?. NBER Working Paper 8524. National Bureau of Economic Research. http://www.nber.org/papers/w8524.

Alesina, A., and E. La Ferrara. 2000. "Participation in Heterogeneous Communities." The Quarterly Journal of Economics 115 (3): 847-904.

Athias, L., and A. Nuñez. 2009. “The More the Merrier? Number of Bidders, Information Dispersion, Renegotiation and Winner's Curse in Toll Road Concessions." http://papers.ssrn.com/sol3/papers.cfm?abstract_id=1269630.

Barrett, K, and R Greene. 2008. "Measuring Performance. The State Management Report Card 2008.” Governing, March.

Beck, T., A. Demirgüç-Kunt, and R. Levine. 2003. "Law and Finance: Why Does Legal Origin Matter?" Journal of Comparative Economics 31 (4): 653-75. doi:10.1016/j.jce.2003.08.001.

Button, Kenneth. 2010. Transport Economics. 3rd ed. Aldershot, Hants, England; Northampton, MA: Elgar.

Caltrans (California Department of Transportation). 2009. “Toll Road Fact Sheet. AB 680 Private Toll Road Program.” http://www.dot.ca.gov/hq/paffairs/about/toll/status.htm.

Chapter 11. Case No. 10-04516-LA11. Declaration of Anthony G. Evans, Chief Financial Officer of South Bay Expressway, L.P., in support of the debtor's chapter 11 petitions and first day motions. 2010. US Bankruptcy Court Southern District of California.

Cirmizi, E., L. Klapper, and M. Uttamchandani. 2012. "The Challenges of Bankruptcy Reform.” The World Bank Research Observer 27 (2): 185-203. doi:10.1093/wbro/lkr012.

Commonwealth of Virginia. 2012. "PPTA Implementation Manual and Guidelines." The Commonwealth of Virginia. http://www.vappta.org/ppta_implementation_manual_guidelines.asp. 
De Brux, J. 2010. "The Dark and Bright Sides of Renegotiation: An Application to Transport Concession Contracts.” Utilities Policy 18 (2): 77-85. doi:10.1016/j.jup.2009.07.003.

Department of the Treasury. 2014. Expanding Our Nation's Infrastructure through Innovative Financing. Washington, D.C.: US Department of the Treasury. http://www.treasury.gov/press-center/pressreleases/Documents/Expanding\%20our\%20Nation\%27s\%20Infrastructure\%20through\%20Innovati ve\%20Financing.pdf.

Engel, E., R. Fischer, and A. Galetovic. 2001. "Least-Present-Value-of-Revenue Auctions and Highway Franchising.” Journal of Political Economy 109 (5): 993-10250.

. 2006. "Privatizing Highways in the United States." Review of Industrial Organization 29 (1-2): 27-53. doi:10.1007/s11151-006-9108-6.

Engel, E., R. Fischer, and A. Galetovic. 2009. Soft Budgets, Renegotiations and Public-Private Partnerships. 15300. NBER Working Paper. National Bureau of Economic Research. http://www.nber.org/papers/w15300.

FHWA. 2014a. "Project Profiles: Dulles Greenway." https://www.fhwa.dot.gov/ipd/project_profiles/va_dulles_greenway.htm.

_. 2014b. "P3 Defined: 63-20 Nonprofit Public Benefit Corporation." http://www.fhwa.dot.gov/ipd/p3/defined/dbfo_6320.aspx.

_. 2014c. "Project Profiles: Pocahontas Parkway." http://www.fhwa.dot.gov/ipd/project_profiles/va_pocahontas.aspx.

_ 2014d. "Project Profiles: Downtown Tunnel / Midtown Tunnel / MLKI Extension." http://www.fhwa.dot.gov/ipd/project_profiles/va_midtown_tunnel.aspx.

_. 2014e. "Project Profiles: 91 Express Lanes." http://www.fhwa.dot.gov/ipd/project_profiles/ca_91expresslanes.aspx.

_. 2014f. "Project Profiles: South Bay Expressway." http://www.fhwa.dot.gov/ipd/project_profiles/ca_southbay.aspx.

Fretz, D. 2010. “PFI - First US TIFIA Road Files for Protection.” Reuters. March 24. http://www.reuters.com/article/2010/03/24/idUSLDE62N29I20100324.

Gilroy, L., and D. Aloyts. 2013. Leasing the Indiana Toll Road: Reviewing the First Six Years Under Private Operation. 108. Policy Brief.

Giuliano, G., L. Schweitzer, K. Holliday, and T. Minch. 2012. "Public Private Partnerships in California. Phase II Report. Section VII: California Political Environment." http://www.metrans.org/sites/default/files/researchproject/Section_VII_California_political_environment.pdf. 
Government Performance Project. 2005. Grading the States 2005: A Look inside. Government Performance Project.

http://www.pewtrusts.org/ /media/legacy/uploadedfiles/wwwpewtrustsorg/reports/government_perf ormance/GPPReport2005pdf.pdf.

Guasch, J. L. 2004. Granting and Renegotiating Infrastructure Concessions Doing It Right. Washington, D.C.: World Bank.

Guasch, J. L., J. J. Laffont, and S. Straub. 2003. Renegotiation of Concession Contracts in Latin America. 3011. World Bank Policy Research Working Paper. Washington, D.C.: World Bank. http://elibrary.worldbank.org/doi/pdf/10.1596/1813-9450-3011.

Guasch, J. L, J. J Laffont, and S Straub. 2006. “Concessions of Infrastructure in Latin America: Government-Led Renegotiation.” Working Paper. University of Edinburgh.

_ 2007. "Concessions of Infrastructure in Latin America: Government-Led Renegotiation.” Journal of Applied Econometrics 22 (7): 1267-94.

Guasch, J. L., J. J. Laffont, and S. Straub. 2008. "Renegotiation of Concession Contracts in Latin America." International Journal of Industrial Organization 26 (2): 421-42. doi:10.1016/j.ijindorg.2007.05.003.

Hart, O, and J Moore. 1988. "Incomplete Contracts and Renegotiation.” Econometrica 56 (4): 755-85.

Hawkins, R. 2011. "SANDAG Officially Takes over South Bay Toll Road." U-T San Diego, December 21. http://www.utsandiego.com/news/2011/dec/21/sandag-officially-takes-over-south-bay-toll$\mathrm{road} /$.

IFA. 2013. "Other Bids.” http://www.in.gov/ifa/files/Other_Bids.pdf.

InfraDeals. 2014. “Assets Owners Database.” http://www.infra-deals.com/public/.

ITF. 2008. Transport Infrastructure Investment: Options for Efficiency. Paris: OECD.

Jensen, R. 2011. "Tollway Exits Chapter 11 -." The Bond Buyer, May 5. http://www.bondbuyer.com/issues/120_87/south_bay_expressway_bankruptcy-1026333-1.html.

Katsivela, M. 2007. "Contracts: Force Majeure Concept or Force Majeure Clauses.” Uniform Law Review 12 (1): 101-19.

King, D, R. G Zeckhauser, and M. T Kim. 2004. The Management Performance of the US States. Harvard Kennedy School Faculty Research Working Paper Series. http://www.hks.harvard.edu/fs/rzeckhau/GradingStatesv1.pdf.

Klein, B., R. G. Crawford, and A. A. Alchian. 1978. "Vertical Integration, Appropriable Rents, and the Competitive Contracting Process.” Journal of Law and Economics 21 (2): 297-326. 
RENEGOTIATION OF TRANSPORTATION PUBLIC-PRIVATE PARTNERSHIPS: THE US EXPERIENCE

KPMG. 2013. "Massachusetts Department of Transportation (MassDOT). P3 Program Comparison." http://www.massdot.state.ma.us/Portals/0/docs/infoCenter/boards_committees/PublicPrivate/P3_Co mparison_101113.pdf.

La Porta, R., F. Lopez-de-Silanes, and A. Shleifer. 2008. "The Economic Consequences of Legal Origins.” Journal of Economic Literature 46 (2): 285-332. doi:10.1257/jel.46.2.285.

Levey, Bob, and Jane Freundel Levey. 2000. "End of the Roads: In the Interstate Era, Congress Ruled Washington like a Fiefdom. Then a Fight over Some Freeways Inspired a Biracial, NeighborhoodLevel Movement to Fight the Federal Power." The Washington Post, November 26, Final Edition, sec. Magazine.

Levy, S. M. 2011. Public-Private Partnerships: Case Studies on Infrastructure Development. Reston, Va: ASCE Press.

Macquarie Atlas Roads. 2009. "Macquarie Atlas Roads Prospectus." https://www.macquarie.com/dafiles/Internet/mgl/mig/docs/prospectus.pdf.

Martz, M. 2014. "Pocahontas 895 Toll Road under a New Operator." Richmond Times, June 17. http://www.timesdispatch.com/news/pocahontas-toll-road-under-a-new-operator/article_94f7e91fe346-57c4-807d-fd7c60fcdb64.html.

Meeks v. Elizabeth River Crossings OPCO, LLC and Virginia Department of Transportation, 2013 VA App. 2013. Circuit Court of the city of Portsmouth.

Metro ExpressLane. 2014. Debt Capacity Assessment. Metro ExpressLane. http://media.metro.net/projects_studies/expresslanes/images/public_reports_exlattachmentc_042014.pdf.

Moszoro, M, and P Spiller. 2012. "Third-Party Opportunism and the Theory of Public Contracts: Operationalization and Applications." In Manufacturing Markets: Legal, Political and Economic Dynamics, edited by Eric Brousseau and Jean-Michel Glachant. Cambridge, UK: Cambridge University Press.

Office of Governor. 2014. "Governor McAuliffe Announces Initial Toll Rates Will Be Cut in Half for the Downtown/Midtown Tunnels Project in Hampton Roads." Virginia Department of Transportation. January 15.

http://www.virginiadot.org/newsroom/statewide/2014/governor_mcauliffe_announces_initial70257. asp.

Olson, Mancur. 2000. Power and Prosperity: Outgrowing Communist and Capitalist Dictatorships. New York: Basic Books.

OTP3 (Office of Transportation Public-Private Partnership. 2014. "Office of Transportation Public-Private Partnerships.” Office of Transportation Public-Private Partnerships. Accessed October 1. http://www.vappta.org/. 
Poythress, K. 2012. "Traffic up on South Bay Expressway.” U-T San Diego. August 20. http://www.utsandiego.com/news/2012/aug/20/traffic-up-on-south-bay-expressway/.

Qian, Y., and B. Weingast. 1997. "Federalism as a Commitment to Preserving Market Incentives." The Journal of Economic Perspectives 11 (4): 83-92.

Reinhardt, W. G. 2012. "Midtown Financial Close Ignites Virginia Politics.” Public Works Financing, April. http://www.pwfinance.net/document/research_reprints/1_Midtown_corrected.pdf.

Rich, R., and J. Tracy. 2013. "Early Contract Renegotiation: An Analysis of US Labor Contracts, 19701995." Journal of Labor Economics 31 (4): 825-42. doi:10.1086/669965.

RoadTraffic-Technology. 2012. "South Bay Expressway, San Diego County, CA - Road Traffic Technology." RoadTraffic-Technology. Accessed December 12. http://www.roadtraffictechnology.com/projects/stateroute125/.

Roberts, M. R., and A. Sufi. 2009. "Renegotiation of Financial Contracts: Evidence from Private Credit Agreements.” Journal of Financial Economics 93 (2): 159-84. doi:10.1016/j.jfineco.2008.08.005.

Samuel, P. 2011. "South Bay Expressway Reorganized out of Bankruptcy.” Toll Roads News, April 16. http://tollroadsnews.com/news/south-bay-expressway-reorganized-out-of-bankruptcy.

. 2012. "Virginia Gone to Financial Close on $\$ 2.1$ b Norfolk Crossings P3, Compromises on Toll Timing, Coverage." Toll Roads News, April 20. http://tollroadsnews.com/news/virginia-gone-tofinancial-close-on-21b-norfolk-crossings-p3-compromises-on-toll-timing-coverage.

_ 2013. "Pocahontas Parkway Turned over to Lenders ADDITIONS -." Toll Roads News, June 14. http://tollroadsnews.com/news/pocahontas-parkway-turned-over-to-lenders-additions.

Saussier, S., C. Staropoli, and A. Yvrande-Billon. 2009. "Public-Private Agreements, Institutions, and Competition: When Economic Theory Meets Facts.” Review of Industrial Organization 35 (1-2): 118. doi:10.1007/s11151-009-9226-z.

Small, k. a. 2010. "Private Provision of Highways: Economic Issues." Transport Reviews 30 (1): 11-31. doi:10.1080/01441640903189288.

Soule, B., and D. Tassin. 2007. "The Otay River Bridge.” Structure Magazine, July.

Tanner, D. 2013. “Virginia Cites High Toll Rates in Proposed 'Buyback' of Private Toll Road.” Land Line Magazine, January 15. http://www.landlinemag.com/Story.aspx?StoryID=24653.

Thaler, Richard H. 1988. “Anomalies: The Winner's Curse.” The Journal of Economic Perspectives 2 (1): 191-202.

USGAO (US Government Accountability Office). 2004. Highways and Transit. Private Sector Sponsorship of and Investment in Major Projects Has Been Limited. USGAO. http://www.gao.gov/new.items/d04419.pdf. 
VDOT. 2006. The History of Roads in Virginia. Virginia: Virginia Department of Transportation. http://www.virginiadot.org/about/resources/historyofrds.pdf.

\section{- 2014. "Governor McAuliffe Announces Initial Toll Rates Will Be Cut in Half Fort He} Downtown/Midtown Tunnels Project in Hampton Roads." Virginia Department of Transportation. January 15.

http://www.virginiadot.org/newsroom/statewide/2014/governor_mcauliffe_announces_initial70257. asp.

Vining, A. R., A. E. Boardman, and F. Poschmann. 2005. "Public-private Partnerships in the US and Canada: 'There Are No Free Lunches."' Journal of Comparative Policy Analysis: Research and Practice 7 (3): 199-220. doi:10.1080/13876980500209363.

Wang, Y. 2010. "Recent Experience In The Utilization Of Private Finance For American Toll Road Development." University Of Southern California. http://digitallibrary.usc.edu/cdm/ref/collection/p15799coll127/id/345049.

Wee, J. 2012. "Public-Private Partnerships: The Project Financing of the Indiana Toll Road - INS190PDF-ENG.” Harvard Business School Publishing. https://cb.hbsp.harvard.edu/cbmp/content/INS190-PDF-ENG.

Williamson, O. E. 1996. The Mechanisms of Governance. New York, N.Y.: Oxford University Press. 


\section{Appendix: Tables and Figures}

\section{Table 1. Outcome of renegotiations in Latin America and the Caribbean, 1985-2000}

\begin{tabular}{|l|c|}
\hline Renegotiation Outcome & $\begin{array}{c}\text { Percentage of } \\
\text { Renegotiated Concession } \\
\text { Contracts with the Given } \\
\text { Outcome }\end{array}$ \\
\hline Delays on investment obligations targets & 69 \\
\hline Acceleration of investment obligations & 18 \\
\hline Tariff increases & 62 \\
\hline Tariff decreases & 19 \\
\hline $\begin{array}{l}\text { Increase in the number of cost components with an automatic pass-through } \\
\text { to tariff increases }\end{array}$ & 39 \\
\hline Extension of concession period & 38 \\
\hline Reduction of investment obligations & 62 \\
\hline $\begin{array}{l}\text { Adjustment of canon - annual fee paid by operator to government: } \\
\text { favorable to operator }\end{array}$ & 31 \\
\hline $\begin{array}{l}\text { Adjustment of canon - annual fee paid by operator to government: } \\
\text { unfavorable to operator }\end{array}$ & \\
\hline Changes in the asset-capital base: favorable to operator & 17 \\
\hline Changes in the asset-capital base: unfavorable to operator & \\
\hline
\end{tabular}

Source: Guasch, 2004. 
Table 2. Geographic distribution of US P3s, renegotiations, and our case studies

\begin{tabular}{|c|c|c|c|c|c|c|c|c|c|c|c|}
\hline \multirow{2}{*}{ State } & \multirow{2}{*}{$\begin{array}{c}\text { P3 } \\
\text { Highways }\end{array}$} & \multicolumn{5}{|c|}{ P3 Highways Facing Renegotiations } & \multicolumn{5}{|c|}{ Cases Under Analysis } \\
\hline & & $\begin{array}{c}\text { Contract } \\
\text { modification }\end{array}$ & Default & Bankruptcy & Buy-out & $\begin{array}{c}\text { Total } \\
\text { Projects }\end{array}$ & $\begin{array}{c}\text { Contract } \\
\text { modification }\end{array}$ & Default & Bankruptcy & Buy-out & $\begin{array}{l}\text { Total } \\
\text { Projects }\end{array}$ \\
\hline Alaska & 1 & 0 & 0 & 0 & 0 & 0 & 0 & 0 & 0 & 0 & 0 \\
\hline California & 4 & 1 & 1 & 1 & 2 & 2 & 1 & 1 & 1 & 2 & 2 \\
\hline Colorado & 2 & 0 & 0 & 0 & 1 & 1 & 0 & 0 & 0 & 0 & 0 \\
\hline Florida & 13 & 0 & 0 & 0 & 1 & 1 & 0 & 0 & 0 & 0 & 0 \\
\hline Georgia & 1 & 0 & 0 & 0 & 0 & 0 & 0 & 0 & 0 & 0 & 0 \\
\hline Indiana & 2 & 1 & 1 & 1 & 1 & 1 & 1 & 1 & 1 & 1 & 1 \\
\hline Massachusetts & 1 & 0 & 0 & 0 & 0 & 0 & 0 & 0 & 0 & 0 & 0 \\
\hline Michigan & 1 & 0 & 0 & 0 & 1 & 1 & 0 & 0 & 0 & 0 & 0 \\
\hline New Mexico & 1 & 1 & 0 & 0 & 0 & 1 & 0 & 0 & 0 & 0 & 0 \\
\hline North Carolina & 1 & 0 & 0 & 0 & 0 & 0 & 0 & 0 & 0 & 0 & 0 \\
\hline South Carolina & 1 & 0 & 1 & 1 & 0 & 1 & 0 & 0 & 0 & 0 & 0 \\
\hline Texas & 10 & 1 & 1 & 1 & 3 & 4 & 0 & 0 & 0 & 0 & 0 \\
\hline Virginia & 6 & 3 & 2 & 1 & 3 & 5 & 2 & 2 & 1 & 1 & 3 \\
\hline TOTAL & 45 & 7 & 6 & 5 & 12 & 17 & 4 & 4 & 3 & 4 & 6 \\
\hline
\end{tabular}

Sources: Public Works Financing Newsletter 2014, InfraDeals 2014. 
Table 3. Summary of US P3 renegotiation cases $(\mathbf{1 9 9 5 - 2 0 1 3})^{17}$

\begin{tabular}{|c|c|c|c|c|c|c|}
\hline Project & State & $\begin{array}{c}\text { Main } \\
\text { Revenue } \\
\text { Source }\end{array}$ & $\begin{array}{l}\text { Contract } \\
\text { Type }\end{array}$ & $\begin{array}{l}\text { Original Cost } \\
\text { Estimate }\end{array}$ & $\begin{array}{c}\text { Final } \\
\text { Construction } \\
\text { Cost }\end{array}$ & $\begin{array}{c}\text { Purchase } \\
\text { Price From } \\
\text { Original } \\
\text { Private } \\
\text { Partners }\end{array}$ \\
\hline $\begin{array}{l}\text { Dulles } \\
\text { Greenway }\end{array}$ & Virginia & Toll & DBFOM & $\begin{array}{l}350 \text { million } \\
\text { (1993) }\end{array}$ & 338 million & $\begin{array}{c}617.5 \text { million } \\
(2005)\end{array}$ \\
\hline $\begin{array}{l}\text { Pocahontas } \\
\text { Parkway }\end{array}$ & Virginia & Toll & DBFOM & $\begin{array}{l}381 \text { million } \\
\text { (1998) }\end{array}$ & $\begin{array}{l}314 \text { million } \\
\text { (2002) }\end{array}$ & $\begin{array}{l}611 \text { million } \\
\text { (2006) }\end{array}$ \\
\hline $\begin{array}{l}\text { Elizabeth } \\
\text { River } \\
\text { Crossings } \\
\end{array}$ & Virginia & Toll & DBFOM & 2089 million & $\mathrm{n} / \mathrm{a}$ & $\mathrm{n} / \mathrm{a}$ \\
\hline $\begin{array}{l}\text { State Route } \\
91\end{array}$ & California & Toll & DBFOM & $\begin{array}{l}88.3 \text { million } \\
(1990)\end{array}$ & $\begin{array}{l}130 \text { million } \\
\text { (1995) }\end{array}$ & $\begin{array}{c}207.5 \text { million } \\
(2003)\end{array}$ \\
\hline $\begin{array}{l}\text { South Bay } \\
\text { Expressway }^{a}\end{array}$ & California & Toll & DBFOM & $\begin{array}{l}400 \text { million } \\
\text { (1990) }\end{array}$ & $\begin{array}{l}722 \text { million } \\
(2007)\end{array}$ & $\begin{array}{c}351.7 \text { million } \\
\text { (2011) }\end{array}$ \\
\hline $\begin{array}{l}\text { Indiana Toll } \\
\operatorname{Road}^{c}\end{array}$ & Indiana & Toll & $\begin{array}{c}\mathrm{DBFOM}+ \\
\mathrm{OM}\end{array}$ & $\mathrm{n} / \mathrm{a}$ & $\mathrm{n} / \mathrm{a}$ & $\mathrm{n} / \mathrm{a}$ \\
\hline
\end{tabular}

Source: Compiled by authors from multiple sources.

${ }^{17}$ DBFOM: Design, Build, Finance, Operate and Maintain. OM: Operate and Maintain.

a. Includes the construction of non-toll 3.2 miles $(5 \mathrm{~km})$.

b. Construction of 1.2 miles $(1.9 \mathrm{~km})$ of tunnel and 1 mile $(1.6 \mathrm{~km})$ of highway. Maintenance of 50 lane mile.

c. Acquisition required the construction of 10 miles $(16.1 \mathrm{~km})$. The upfront payment was USD 3778 million. 
Table 4. Complexity in the design and construction of $\mathbf{P 3}$ cases $^{\mathbf{1 8}}$

\begin{tabular}{|l|l|c|c|c|}
\hline Project & State & $\begin{array}{c}\text { Constructed Length } \\
\text { miles }(\mathrm{km})\end{array}$ & Bridges \\
\hline Dulles Greenway & Virginia & $14(22.5)$ & Yes & No \\
\hline Pocahontas Parkway & Virginia & $8.8(14.1)$ & Yes & No \\
\hline Elizabeth River Crossings & Virginia & $2.2(3.5)$ & Yes & Yes \\
\hline State Route 91 & California & $10(16.1)$ & No & No \\
\hline South Bay Expressway & California & $12.7(20.4)$ & Yes & No \\
\hline Indiana Toll Road & Indiana & $10(16.1)^{*}$ & No & No \\
\hline
\end{tabular}

Source: Compiled by authors from multiple sources.

18 Indiana Toll Road includes the operation and maintenance of the originally constructed $2+2$ lanes for 156 miles $(251 \mathrm{~km})$. In addition it includes the design, construction, finance, operation and maintenance of a third line, in each direction, for 10 miles $(16.1 \mathrm{~km})$. 
Table 5. Summary of P3 Renegotiation cases (1993-2013)

\begin{tabular}{|c|c|c|c|c|c|}
\hline Project & Return & Tolls & Problems & Dates & Relevant dates \\
\hline \multirow{10}{*}{ Dulles Greenway } & \multirow{10}{*}{$\begin{array}{l}\text { From } 30 \% \text { down } \\
\text { to } 14 \%\end{array}$} & \multirow{10}{*}{$\begin{array}{l}\text { Tolls regulated by } \\
\text { Virginia State } \\
\text { Corporation } \\
\text { Commission }\end{array}$} & \multirow{10}{*}{$\begin{array}{c}\text { Demand lower than } \\
\text { expected }\end{array}$} & 1993 & Financial close \\
\hline & & & & 1993 & Construction starts \\
\hline & & & & 1995 & Opening year \\
\hline & & & & 1995 & Tolls decreased. Owners default on debt. \\
\hline & & & & 1997 & Tolls increased. Speed limit increased $(65 \mathrm{mph})$ \\
\hline & & & & 1999 & Debt restructured. Project modified: from $2 * 2$ lanes to $3 * 3$. \\
\hline & & & & 2001 & Extension of concession period (20 years) \\
\hline & & & & 2004 & Variable peak and discounted off-peak point-to-point rates \\
\hline & & & & 2005 & Macquarie Infrastructure Group purchases P3 \\
\hline & & & & 2013 & Tolls (2013-2020): the higher of CPI plus $1 \%$, real GDP, or $2.8 \%$. \\
\hline \multirow{7}{*}{ Pocahontas Parkway } & \multirow{7}{*}{$\begin{array}{l}\text { Originally not-for- } \\
\text { profit }\end{array}$} & \multirow{7}{*}{$\begin{array}{l}\text { First } 2 \text { years in } \\
\text { contract. VDOT } \\
\text { adjusts afterwards }\end{array}$} & \multirow{4}{*}{$\begin{array}{c}\text { Demand lower than } \\
\text { expected }\end{array}$} & 1998 & Financial close \\
\hline & & & & 1998 & Construction starts \\
\hline & & & & 2002 & Opening year \\
\hline & & & & 2006 & Transurban USA purchases the contract for: Lease Develop-Operate \\
\hline & & & & & $\begin{array}{l}\text { Extension of concession period (to } 99 \text { years) } \\
\text { Additional investments: } 1.6 \text {-mile (2.6km), four-lane (Airport Connector), } \\
\text { and electronic tolling }\end{array}$ \\
\hline & & & & 2012 & Transurban USA writes off its equity on the parkway to zero. \\
\hline & & & & 2014 & Transurban USA transfers the operation to DBi Services \\
\hline \multirow{5}{*}{$\begin{array}{l}\text { Elizabeth River } \\
\text { Crossings }\end{array}$} & \multirow{5}{*}{$\begin{array}{l}\text { Revenue-sharing } \\
\text { after threshold }\end{array}$} & \multirow{5}{*}{$\begin{array}{l}\text { Highest of } 3.5 \% \text { or } \\
\text { CPI }\end{array}$} & \multirow{5}{*}{$\begin{array}{l}\text { Community } \\
\text { opposition }\end{array}$} & 2012 & Financial close \\
\hline & & & & 2012 & Construction starts \\
\hline & & & & 2012 & $\begin{array}{l}\text { Delays tolling until } 2014 \text { in exchange for } \$ 125 \text { million. Private partners } \\
\text { increased equity by } \$ 207 \text { million. }\end{array}$ \\
\hline & & & & 2014 & Tolls are decreased. Compensation USD 82.5. \\
\hline & & & & 2017 & Expected opening \\
\hline
\end{tabular}


Table 5. (continued) Summary of P3 Renegotiation cases (1993-2013)

\begin{tabular}{|c|c|c|c|c|c|}
\hline Project & Return & Tolls & Problems & Dates & Relevant dates \\
\hline \multirow{4}{*}{ State Route 91} & \multirow{4}{*}{$17 \%$} & & \multirow[t]{4}{*}{ Non-compete clause } & 1993 & Financial close \\
\hline & & & & 1993 & Construction starts \\
\hline & & & & 1995 & Opening year \\
\hline & & & & 2003 & Orange County (OCTA) purchases it to eliminate non-compete clause \\
\hline \multirow{5}{*}{$\begin{array}{l}\text { South Bay } \\
\text { Expressway }\end{array}$} & \multirow{5}{*}{$18.50 \%$} & \multirow{5}{*}{-} & & 2002 & Macquarie Infrastructure Group (MIG) purchases CTV \\
\hline & & & & 2003 & Financial close \\
\hline & & & & 2007 & Opening year \\
\hline & & & & 2010 & Files for bankruptcy \\
\hline & & & & 2011 & $\begin{array}{l}\text { Exits Chapter } 11 \text { as San Diego Association of Governments (SANDAG) } \\
\text { purchases it. Tolls are decreased. }\end{array}$ \\
\hline \multirow{9}{*}{ Indiana Toll Road } & \multirow{9}{*}{-} & \multirow{9}{*}{ Inflation cap } & \multirow{9}{*}{-} & 2006 & Financial close \\
\hline & & & & 2006 & Opening year \\
\hline & & & & 2006 & $\begin{array}{l}\text { "Toll freeze" until electronic tolling is in place. State reimbursement } \\
\text { amounts to USD } 60 \text { million }\end{array}$ \\
\hline & & & & 2006 & Reduction on investment obligations \\
\hline & & & & 2007 & Construction starts \\
\hline & & & & 2007 & Delays in certain investments until 2010 \\
\hline & & & & 2008 & State reimbursement amounts to USD 60 million due to lost revenue \\
\hline & & & & 2010 & Delays in certain investments until 2011 \\
\hline & & & & 2014 & Filed for bankruptcy \\
\hline
\end{tabular}

Source: Compiled by authors from multiple sources. 
Table 6. Outcome of renegotiations in the US highway P3 cases (1995-2013) ${ }^{19}$

\begin{tabular}{|c|c|c|c|c|c|c|}
\hline Renegotiation Outcome & $\begin{array}{l}\text { Dulles } \\
\text { Greenway }\end{array}$ & $\begin{array}{l}\text { Pocahontas } \\
\text { Parkway }\end{array}$ & $\begin{array}{l}\text { Midtown and } \\
\text { Downtown } \\
\text { Tunnels }\end{array}$ & $\begin{array}{l}\text { State Route } \\
91\end{array}$ & $\begin{array}{l}\text { South Bay } \\
\text { Expressway }\end{array}$ & Indiana Toll Road \\
\hline Delays on investment obligations targets & No & No & No & No & No & Yes \\
\hline Acceleration of investment obligations & No & No & No & No & No & No \\
\hline Tariff increases & Yes & No & No & No & No & No \\
\hline Tariff decreases or freeze or delay & Yes & No & Yes & No & Yes & Yes \\
\hline $\begin{array}{l}\text { Increase in the number of cost components } \\
\text { with an automatic pass-through to tariff } \\
\text { increases }\end{array}$ & No & No & No & No & No & No \\
\hline Extension of concession period & Yes & Yes & No & No & No & No \\
\hline Reduction of investment obligations & No & No & No & No & No & Yes \\
\hline $\begin{array}{l}\text { Adjustment of canon -annual fee paid by } \\
\text { operator to government: favorable to } \\
\text { operator }\end{array}$ & No & No & No & No & No & No \\
\hline $\begin{array}{l}\text { Adjustment of canon -annual fee paid by } \\
\text { operator to government: unfavorable to } \\
\text { operator }\end{array}$ & No & No & No & No & No & No \\
\hline $\begin{array}{l}\text { Changes in the asset-capital base: favorable } \\
\text { to operator }\end{array}$ & No & No & No & No & No & No \\
\hline
\end{tabular}


Table 6. (continued) Outcome of renegotiations in the US highway P3 cases (1995-2013)

\begin{tabular}{|c|c|c|c|c|c|c|}
\hline Renegotiation Outcome & $\begin{array}{l}\text { Dulles } \\
\text { Greenway }\end{array}$ & $\begin{array}{l}\text { Pocahontas } \\
\text { Parkway }\end{array}$ & $\begin{array}{l}\text { Midtown and } \\
\text { Downtown } \\
\text { Tunnels }\end{array}$ & $\begin{array}{l}\text { State Route } \\
91\end{array}$ & $\begin{array}{l}\text { South Bay } \\
\text { Expressway }\end{array}$ & Indiana Toll Road \\
\hline $\begin{array}{l}\text { Changes in the asset-capital base: } \\
\text { unfavorable to operator }\end{array}$ & No & No & Yes & No & No & No \\
\hline Other: increase speed & Yes & No & No & No & No & No \\
\hline Other: additional investment & Yes & Yes & No & No & No & No \\
\hline Other: decrease in investment & No & No & No & No & No & Yes \\
\hline Other: eliminate non-compete clause & No & No & No & Yes & No & No \\
\hline Renegotiation initiated by & Private & Private & Public & Public & Private & Private \\
\hline
\end{tabular}

Sources: IFA, 2014; Levy, 2011; FHWA 2014; Wang, 2010. 
Table 7. Changes in the majority party, state executive and legislative branches

\begin{tabular}{|l|c|c|c|}
\hline State & $\begin{array}{c}\text { Years of changes in } \\
\text { Governor's Party }\end{array}$ & $\begin{array}{c}\text { Years of changes in State } \\
\text { Senate Majority Party }\end{array}$ & $\begin{array}{c}\text { Years of changes in State } \\
\text { House Majority Party }\end{array}$ \\
\hline Virginia & $1993,2002,2009$ & $1995,2008,2011$ & 1997 \\
\hline California & $1999,2003,2011$ & None & 1995,1997 \\
\hline Indiana & 2004 & None & $1994,1999,2004,2010$ \\
\hline
\end{tabular}

Source: Lucy Burns Institute. 2014; Ballotpedia, 2014. 
RENEGOTIATION OF TRANSPORTATION PUBLIC-PRIVATE PARTNERSHIPS: THE US EXPERIENCE

Table 8. Primary private owners and their road asset portfolio facing renegotiations

\begin{tabular}{|c|c|c|c|c|}
\hline Project & Dates & $\begin{array}{c}\text { Main Private Stockholders Behind the } \\
\text { Project }\end{array}$ & Asset Portfolio of Other Roads of Stockholders (2012) & $\begin{array}{l}\text { Asset Portfolio of Other Roads Facing renegotiation } \\
\qquad(\mathbf{2 0 1 2})\end{array}$ \\
\hline \multirow{9}{*}{ Dulles Greenway } & 1993 & \multirow{6}{*}{ Shenandoah Group, Kellog Brown \& Root } & \multirow{6}{*}{ None } & \multirow{6}{*}{ None } \\
\hline & 1995 & & & \\
\hline & 1997 & & & \\
\hline & 1999 & & & \\
\hline & 2001 & & & \\
\hline & 2004 & & & \\
\hline & 2005 & $\begin{array}{l}\text { Macquarie Infrastructure Group (now } \\
\text { Macquarie Atlas Roads) }\end{array}$ & $\begin{array}{l}\text { B103, Indiana Toll Road, M6 Motorway Toll, Societes des } \\
\text { Autoroutes Paris-Rhin-Rhone }\end{array}$ & $\begin{array}{l}\text { Indiana Toll Road, M6 Motorway Toll, Societes des } \\
\text { Autoroutes Paris-Rhin-Rhone }\end{array}$ \\
\hline & 2006 & Macquarie Infrastructure Group and & B103, Indiana Toll Road, M6 Motorway Toll, Societes des & Indiana Toll Road, M6 Motorway Toll, Societes des \\
\hline & 2013 & Macquarie Infrastructure Partners & Autoroutes Paris-Rhin-Rhone, Autoroute A25 & Autoroutes Paris-Rhin-Rhone \\
\hline \multirow{4}{*}{$\begin{array}{l}\text { Pocahontas } \\
\text { Parkway }\end{array}$} & 1998 & \multirow[t]{2}{*}{ Fluor Daniel and Morrison Knudsen } & \multirow{2}{*}{$\begin{array}{l}\text { A59 Motorway Project, I-495 Capital Beltway HOT Lane } \\
\text { Project, I-95 HOV/HOT Lanes Project, Windsor-Essex } \\
\text { Parkway }\end{array}$} & \multirow[t]{2}{*}{ A59 Motorway Project } \\
\hline & 2006 & & & \\
\hline & 2012 & $\begin{array}{l}\text { Transurban DRIVe (owned by Transurban } \\
\text { Group and Capital Partners, now CP2) }\end{array}$ & $\begin{array}{l}\text { I-495 Capital Beltway HOT Lane Project, I-95 HOV/HOT } \\
\text { Lanes Project }\end{array}$ & None \\
\hline & 2014 & Dbi Services & None & None \\
\hline \multirow[t]{2}{*}{ State Route 91} & 1993 & $\begin{array}{l}\text { Level } 3 \text { Communications, Inc., Compagnie } \\
\text { Financière et Industrielle des Autoroutes } \\
\text { (Cofiroute owned by Vinci Autoroute), and } \\
\text { Granite Construction Inc. }\end{array}$ & None & None \\
\hline & 2003 & N/A & None & None \\
\hline
\end{tabular}


Table 8. (continued) Primary private owners and their road asset portfolio facing renegotiations

\begin{tabular}{|c|c|c|c|c|}
\hline Project & Dates & Main Private Stockholders Behind the Project & Asset Portfolio of Other Roads of Stockholders (2012) & $\begin{array}{l}\text { Asset Portfolio of Other Roads Facing Renegotiation } \\
\text { (2012) }\end{array}$ \\
\hline \multirow{3}{*}{$\begin{array}{l}\text { Elizabeth River } \\
\text { Crossings }\end{array}$} & 2012 & \multirow{3}{*}{$\begin{array}{l}\text { Skanska Infrastructure Development, } \\
\text { Macquarie Infrastructure Partners II, and } \\
\text { Macquarie Mercer Infrastructure Trust }\end{array}$} & \multirow{3}{*}{$\begin{array}{l}\text { A1 Motorway, Antofagasta Regional Highway, M25 } \\
\text { Widening Scheme, }\end{array}$} & \multirow{3}{*}{ A1 Motorway, Antofagasta Regional Highway } \\
\hline & 2012 & & & \\
\hline & 2014 & & & \\
\hline \multirow{6}{*}{$\begin{array}{l}\text { South Bay } \\
\text { Expressway }\end{array}$} & 1991 & $\begin{array}{l}\text { Parsons Brinkerhoff, Egis Projects, Fluor } \\
\text { Daniel and Prudential Bache }\end{array}$ & $\begin{array}{l}\text { A59 Motorway Project, HSL/Zuid, I-495 Capital Beltway } \\
\text { HOT Lane Project, I-95 HOV/HOT Lanes Project, } \\
\text { Windsor-Essex Parkway, A2 Motorway PPP Phase 1, } \\
\text { A24/IP3 Viseu-Chaves, A28 Rouen-Alencon Motorway, } \\
\text { A63 Highay, A8, A88 Motorway Falaise-Sées, L2 Bypass } \\
\text { Marseille, M25 Widening Scheme, M6 Motorway Phase } \\
\text { III, North Luzon Expressway, Ostregion PPP Package } 1\end{array}$ & A59 Motorway Project \\
\hline & 1992 & Parsons Brinkerhoff, and Egis Projects & $\begin{array}{l}\text { A2 Motorway PPP Phase 1, A24/IP3 Viseu-Chaves, A28 } \\
\text { Rouen-Alencon Motorway, A63 Highay, A8 (Augsburg- } \\
\text { Munich), A88 Motorway Falaise-Sées, L2 Bypass } \\
\text { Marseille, M25 Widening Scheme, M6 Motorway Phase } \\
\text { III, North Luzon Expressway, Ostregion PPP Package } 1\end{array}$ & $\begin{array}{l}\text { A2 Motorway PPP Phase 1, A24/IP3 Viseu-Chaves, A8 } \\
\text { (Augsburg-Munich), }\end{array}$ \\
\hline & 1997 & $\begin{array}{l}\text { Parsons Brinkerhoff, Egis Projects, and Koch } \\
\text { Industries }\end{array}$ & $\begin{array}{l}\text { A2 Motorway PPP Phase 1, A24/IP3 Viseu-Chaves, A28 } \\
\text { Rouen-Alencon Motorway, A63 Highay, A8, A88 } \\
\text { Motorway Falaise-Sées, L2 Bypass Marseille, M25 } \\
\text { Widening Scheme, M6 Motorway Phase III, North Luzon } \\
\text { Expressway, Ostregion PPP Package } 1\end{array}$ & $\begin{array}{l}\text { A2 Motorway PPP Phase 1, A24/IP3 Viseu-Chaves, A8 } \\
\text { (Augsburg-Munich), }\end{array}$ \\
\hline & 2002 & \multirow{3}{*}{ Macquarie Infrastructure Group } & \multirow{3}{*}{$\begin{array}{l}\text { B103, Indiana Toll Road, M6 Motorway Toll, Societes des } \\
\text { Autoroutes Paris-Rhin-Rhone }\end{array}$} & \multirow{3}{*}{$\begin{array}{l}\text { Indiana Toll Road, M6 Motorway Toll, Societes des } \\
\text { Autoroutes Paris-Rhin-Rhone }\end{array}$} \\
\hline & 2003 & & & \\
\hline & 2010 & & & \\
\hline
\end{tabular}


Table 8. (continued) Primary private owners and their road asset portfolio facing renegotiations

\begin{tabular}{|c|c|c|c|c|}
\hline Project & Dates & $\begin{array}{l}\text { Main Private Stockholders Behind the } \\
\text { Project }\end{array}$ & Asset Portfolio of Other Roads of Stockholders (2012) & $\begin{array}{l}\text { Asset Portfolio of Other Roads Facing } \\
\text { Renegotiation (2012) }\end{array}$ \\
\hline & 2011 & $\begin{array}{l}\text { Banks: DEPFA Bank plc, Allied Irish, Bank } \\
\text { of Ireland, BNP Paribas, Commonwealth } \\
\text { Bank, DVB Bank, DZ Bank, and HSH } \\
\text { Nordbank }\end{array}$ & None & None \\
\hline \multirow{8}{*}{ Indiana Toll Road } & 2006 & \multirow{6}{*}{$\begin{array}{l}\text { Cintra Concesiones de Infraestructuras de } \\
\text { Transporte, Macquarie Infrastructure Partners, } \\
\text { and Macquarie Atlas Roads }\end{array}$} & \multirow{6}{*}{$\begin{array}{l}\text { A-22 Algarve Shadow Toll Road, A-27/28 Norte Litoral Shadow } \\
\text { Toll Road, A-66 Motorway - Benavente to Zamora, Acores } \\
\text { Shadow oll Road, AP-36 Ocana-La Roda Highway, C-16 Sant } \\
\text { Cugat-Terrassa-Manresa Highway, Central Greece E-65 Highway } \\
\text { Project, Costa del Sol Hghway - Ausol II, Costa del Sol Highway - } \\
\text { Ausol I, Highway 407, Highway 407 East to Highway 35/115, } \\
\text { I-635, Ionian Roads Project, M-203 Alcalá O`Donnell Highway, } \\
\text { M-30 Ring Road PPP, M3 Clonee-Kells, Madrid-Ocaña Highway } \\
\text { Concession, N4/N6 PPP, North Tarrant Expressway, North Tarrant } \\
\text { Expressway Segments 3A and 3B, Trans-Texas Corridor SH130 } \\
\text { SEg 5\&6, B103, Dulles Greenway, M6 Motorway Toll, Societes } \\
\text { des Autoroutes Paris-Rhin-Rhone, Autoroute A25, Dulles } \\
\text { Greenway }\end{array}$} & \multirow{6}{*}{$\begin{array}{l}\text { A-22 Algarve Shadow Toll Road, A-27/28 Norte } \\
\text { Litoral Shadow Toll Road, AP-36 Ocana-La } \\
\text { Roda Highway, C-16 Sant Cugat-Terrassa- } \\
\text { Manresa Highway, Highway 407, M-203 Alcalá } \\
\text { O’Donnell Highway, Madrid-Ocaña Highway } \\
\text { Concession, Dulles Greenway }\end{array}$} \\
\hline & 2006 & & & \\
\hline & 2006 & & & \\
\hline & 2007 & & & \\
\hline & & & & \\
\hline & 2008 & & & \\
\hline & 2009 & \multirow[b]{2}{*}{$\begin{array}{l}\text { Ferrovial, Macquarie Infrastructure Partners, } \\
\text { and Macquarie Atlas Roads }\end{array}$} & \multirow{2}{*}{$\begin{array}{l}\text { A-22 Algarve Shadow Toll Road, A-27/28 Norte Litoral Shadow } \\
\text { Toll Road, A-66 Motorway - Benavente to Zamora, Acores Shadow } \\
\text { oll Road, AP-36 Ocana-La Roda Highway, C-16 Sant Cugat- } \\
\text { Terrassa-Manresa Highway, Central Greece E-65 Highway Project, } \\
\text { Costa del Sol Hghway - Ausol II, Costa del Sol Highway - Ausol I, } \\
\text { Highway 407, Highway } 407 \text { East to Highway 35/115, I-635, Ionian } \\
\text { Roads Project, M-203 Alcalá O’Donnell Highway, M-30 Ring Road } \\
\text { PPP, M3 Clonee-Kells, Madrid-Ocaña Highway Concession, N4/N6 } \\
\text { PPP, North Tarrant Expressway, North Tarrant Expressway } \\
\text { Segments 3A and 3B, Trans-Texas Corridor SH130 SEg 5\&6, B103, } \\
\text { Dulles Greenway, M6 Motorway Toll, Societes des Autoroutes } \\
\text { Paris-Rhin-Rhone, Autoroute A25, Dulles Greenway }\end{array}$} & \multirow{2}{*}{$\begin{array}{l}\text { A-22 Algarve Shadow Toll Road, A-27/28 Norte } \\
\text { Litoral Shadow Toll Road, AP-36 Ocana-La } \\
\text { Roda Highway, C-16 Sant Cugat-Terrassa- } \\
\text { Manresa Highway, Highway 407, M-203 Alcalá } \\
\text { O’Donnell Highway, Madrid-Ocaña Highway } \\
\text { Concession, Dulles Greenway }\end{array}$} \\
\hline & 2014 & & & \\
\hline
\end{tabular}

Source: InfraDeals, 2014. 
Table 9. Contract complexity of $\mathbf{P 3}$ cases $^{20}$

\begin{tabular}{|c|c|c|c|c|c|}
\hline Project & State & $\begin{array}{l}\text { Type of } \\
\text { Contract }\end{array}$ & $\begin{array}{c}\text { Original } \\
\text { Contract } \\
\text { Duration } \\
\text { (years) }\end{array}$ & $\begin{array}{c}\text { Is the contract } \\
\text { available } \\
\text { online? }\end{array}$ & $\begin{array}{c}\text { Original } \\
\text { Contract Length } \\
\text { (pages without } \\
\text { exhibits) }\end{array}$ \\
\hline Dulles Greenway & Virginia & DBFOM & 40 & Yes & 61 \\
\hline Pocahontas Parkway & Virginia & $\begin{array}{l}\text { Original: } \\
\text { DBOT. } \\
\text { Modified: } \\
\text { BOT }\end{array}$ & 30 & Yes & 96 \\
\hline $\begin{array}{l}\text { Elizabeth River } \\
\text { Crossings }\end{array}$ & Virginia & DBFOM & 75 & Yes & 160 \\
\hline State Route 91 & California & BTO & 35 & No & * \\
\hline $\begin{array}{l}\text { South Bay } \\
\text { Expressway }\end{array}$ & California & BTO & 35 & No & * \\
\hline Indiana Toll Road & Indiana & $\begin{array}{c}\text { DBFOM + } \\
\text { OM }\end{array}$ & 58 & Yes & 112 \\
\hline
\end{tabular}

Source: Compiled by authors from multiple sources.

${ }^{20}$ No information was available on the California P3 highway contracts. 
Table 10. Fractionalization Index for the United States (2010)

\begin{tabular}{|c|c|}
\hline US State & Ethnic Fractionalization \\
\hline Maine & 0.1166 \\
\hline West Virginia & 0.1391 \\
\hline North Dakota & 0.2214 \\
\hline Minnesota & 0.3431 \\
\hline Wisconsin & 0.3464 \\
\hline Ohio & 0.3495 \\
\hline Missouri & 0.3564 \\
\hline Indiana & 0.3733 \\
\hline Pennsylvania & 0.4018 \\
\hline Tennessee & 0.4364 \\
\hline Utah & 0.4433 \\
\hline Oregon & 0.4631 \\
\hline Arkansas & 0.4717 \\
\hline Massachusetts & 0.4790 \\
\hline Alabama & 0.5113 \\
\hline Washington & 0.5398 \\
\hline Mississippi & 0.5439 \\
\hline South Carolina & 0.5456 \\
\hline Louisiana & 0.5547 \\
\hline Connecticut & 0.5548 \\
\hline Delaware & 0.5759 \\
\hline Colorado & 0.5812 \\
\hline North Carolina & 0.5829 \\
\hline Virginia & 0.5831 \\
\hline Alaska & 0.5915 \\
\hline Illinois & 0.6362 \\
\hline Georgia & 0.6370 \\
\hline Florida & 0.6451 \\
\hline Maryland & 0.6511 \\
\hline Arizona & 0.7041 \\
\hline Texas & 0.7238 \\
\hline Nevada & 0.7440 \\
\hline Hawaii & 0.7521 \\
\hline California & 0.7665 \\
\hline
\end{tabular}

Source: US Census Bureau, 2013. 
Table 11. Ethnic fractionalization of select countries

\begin{tabular}{|l|l|c|}
\hline & Country & Ethnic Fractionalization \\
\hline Maximum value & Uganda & 0.9302 \\
\hline Percentile 90 & Gambia & 0.7864 \\
\hline Percentile 75 & Nepal & 0.6625 \\
\hline Percentile 50 & Palau & 0.4342 \\
\hline Percentile 25 & El Salvador & 0.1984 \\
\hline Percentile 10 & Cyprus & 0.0938 \\
\hline Minimum value & Comoros & 0.0000 \\
\hline
\end{tabular}

Source: Alesina et al., 2003. 
Table 12. The State Management Report Card: Infrastructure Grade, States with P3 Enabling Legislation

\begin{tabular}{|c|c|c|c|}
\hline US States & 1999 & 2005 & 2008 \\
\hline Alabama & 1 & 2 & 6 \\
\hline Alaska & 6 & 6 & 4 \\
\hline Arizona & 3 & 7 & 7 \\
\hline Arkansas & 5 & 6 & 6 \\
\hline California & 4 & 5 & 7 \\
\hline Colorado & 5 & 6 & 6 \\
\hline Connecticut & 6 & 6 & 6 \\
\hline Delaware & 8 & 9 & 9 \\
\hline Florida & 5 & 9 & 10 \\
\hline Georgia & 5 & 6 & 8 \\
\hline Illinois & 7 & 6 & 5 \\
\hline Indiana & 5 & 7 & 9 \\
\hline Louisiana & 8 & 6 & 6 \\
\hline Maine & 4 & 8 & 6 \\
\hline Maryland & 10 & 10 & 9 \\
\hline Massachusetts & 9 & 4 & 3 \\
\hline Minnesota & 10 & 8 & 6 \\
\hline Mississippi & 8 & 6 & 6 \\
\hline Missouri & 10 & 7 & 9 \\
\hline Nevada & 9 & 9 & 7 \\
\hline North Carolina & 9 & 6 & 7 \\
\hline North Dakota & 9 & 7 & 7 \\
\hline Ohio & 8 & 10 & 7 \\
\hline Oregon & 7 & 8 & 6 \\
\hline Pennsylvania & 8 & 9 & 7 \\
\hline South Carolina & 7 & 6 & 4 \\
\hline Tennessee & 7 & 7 & 8 \\
\hline Texas & 5 & 7 & 8 \\
\hline Utah & 10 & 11 & 11 \\
\hline Virginia & 11 & 10 & 9 \\
\hline Washington & 11 & 8 & 9 \\
\hline West Virginia & 6 & 5 & 4 \\
\hline Wisconsin & 10 & 5 & 7 \\
\hline
\end{tabular}

Source: Compiled by authors from multiple sources. 
Figure 1. Number of DB \& P3s Financial Closes in the US by Sector, 1986-2013 ${ }^{21}$

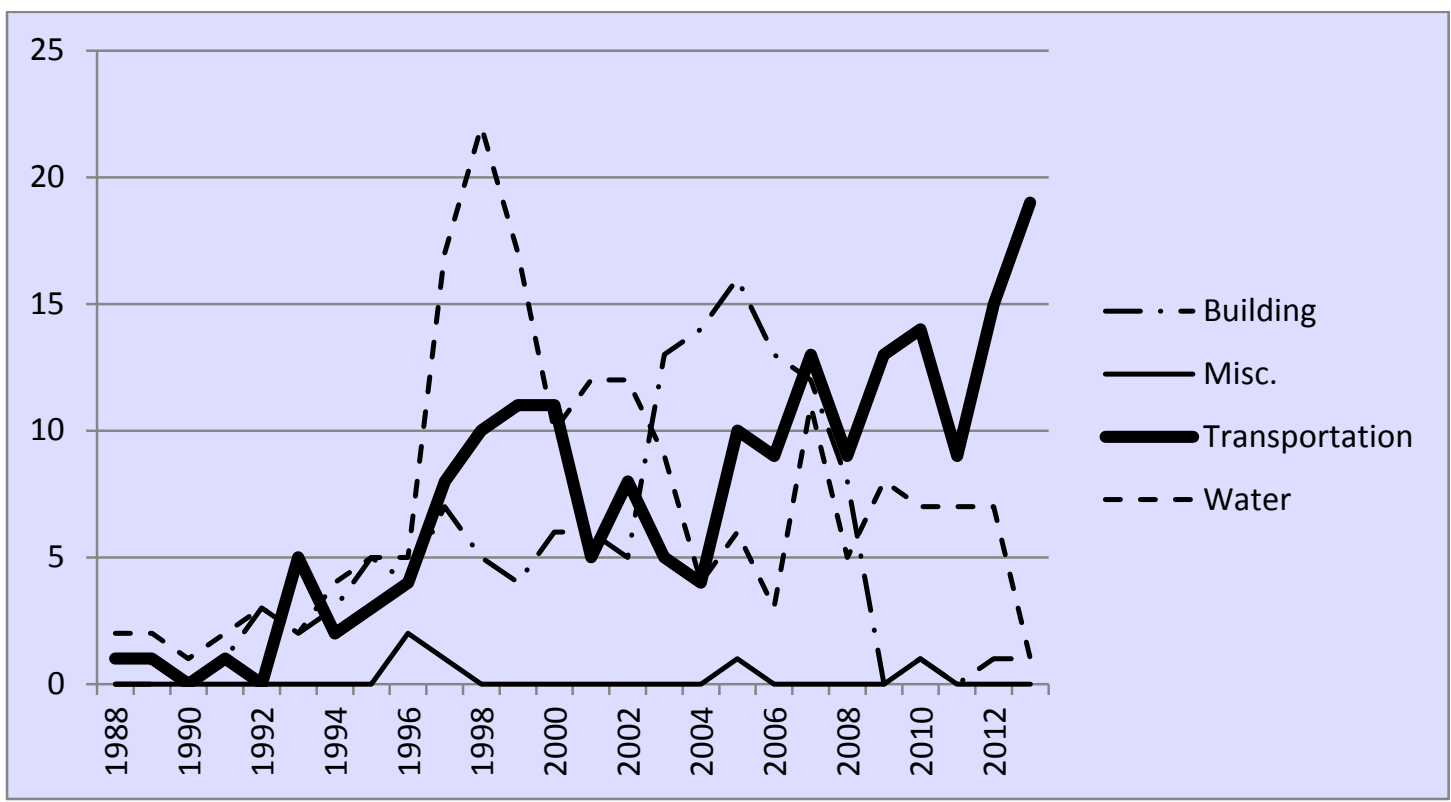

Sources: $\quad$ Public Works Financing Newsletter, 2014.

Figure 2. Cumulative Highway P3 Financial Closes, Total \& Renegotiations, 1993-2014

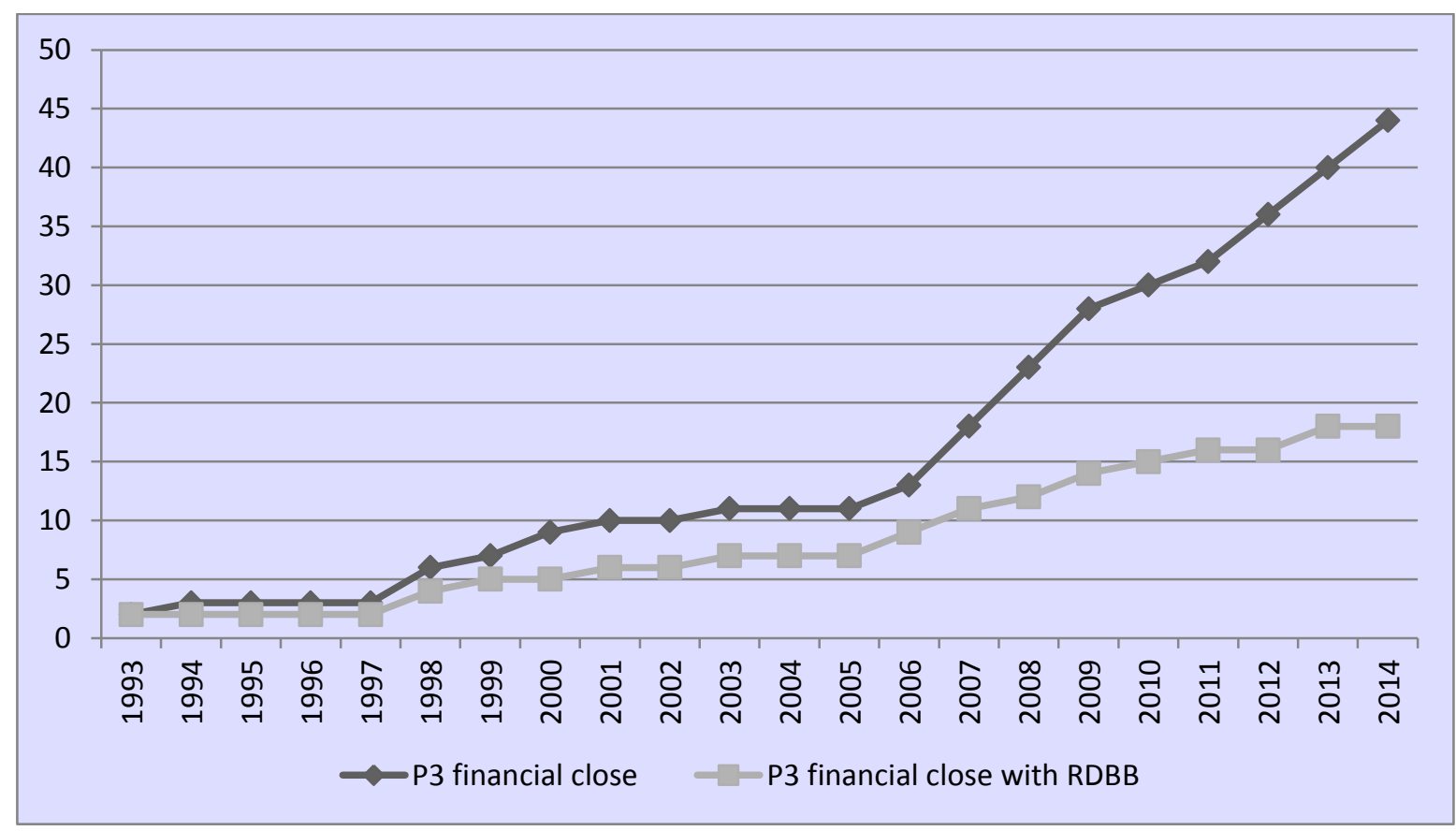

Sources: Public Works Financing Newsletter, 2014.

${ }^{21} \mathrm{P} 3 \mathrm{~s}$ of all contract types, including concessions, management contracts and Design-Build contracts. 
Figure 3. Consumer Price Index - All urban consumers (1992-2014)

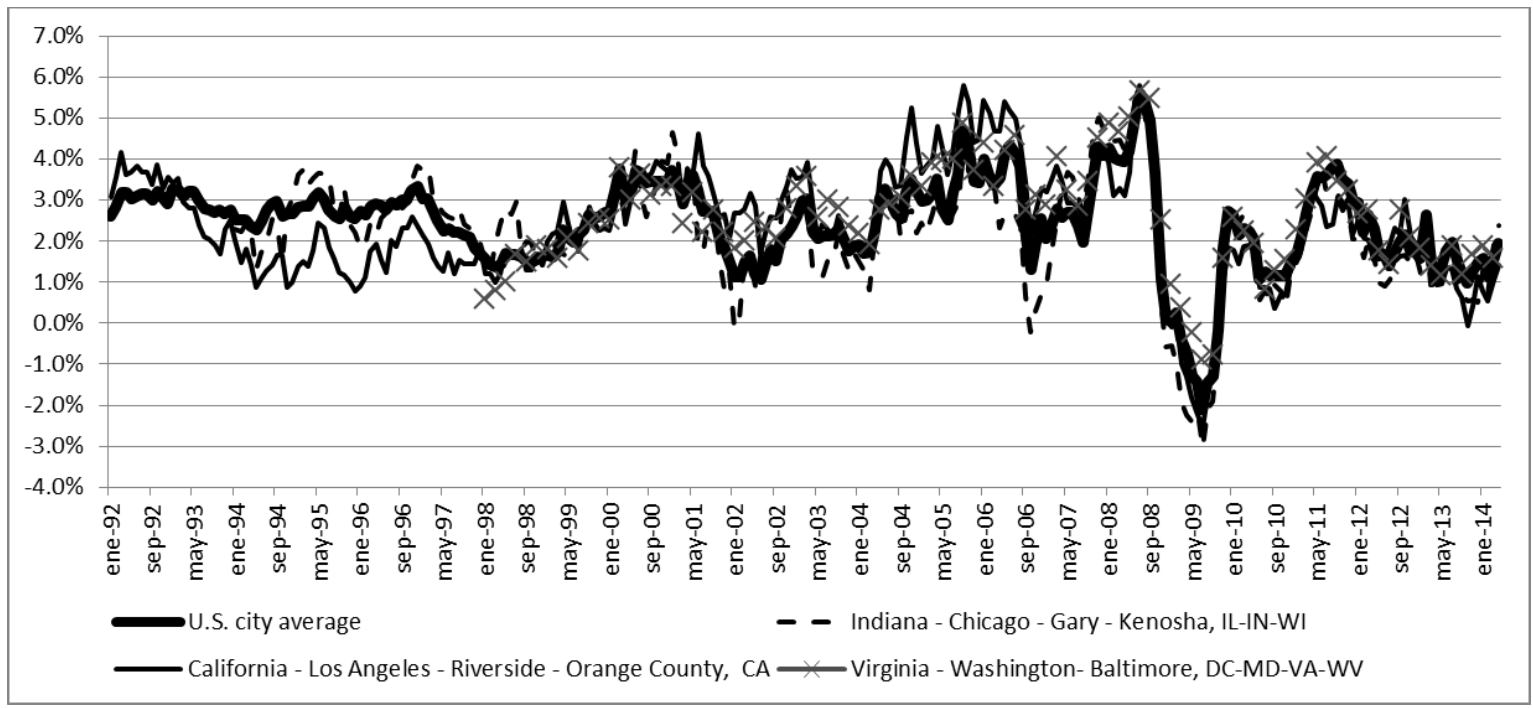

Source: $\quad$ Bureau of Labor Statistics. 2014.

Figure 4. Real GDP growth in select states (1992-2014)

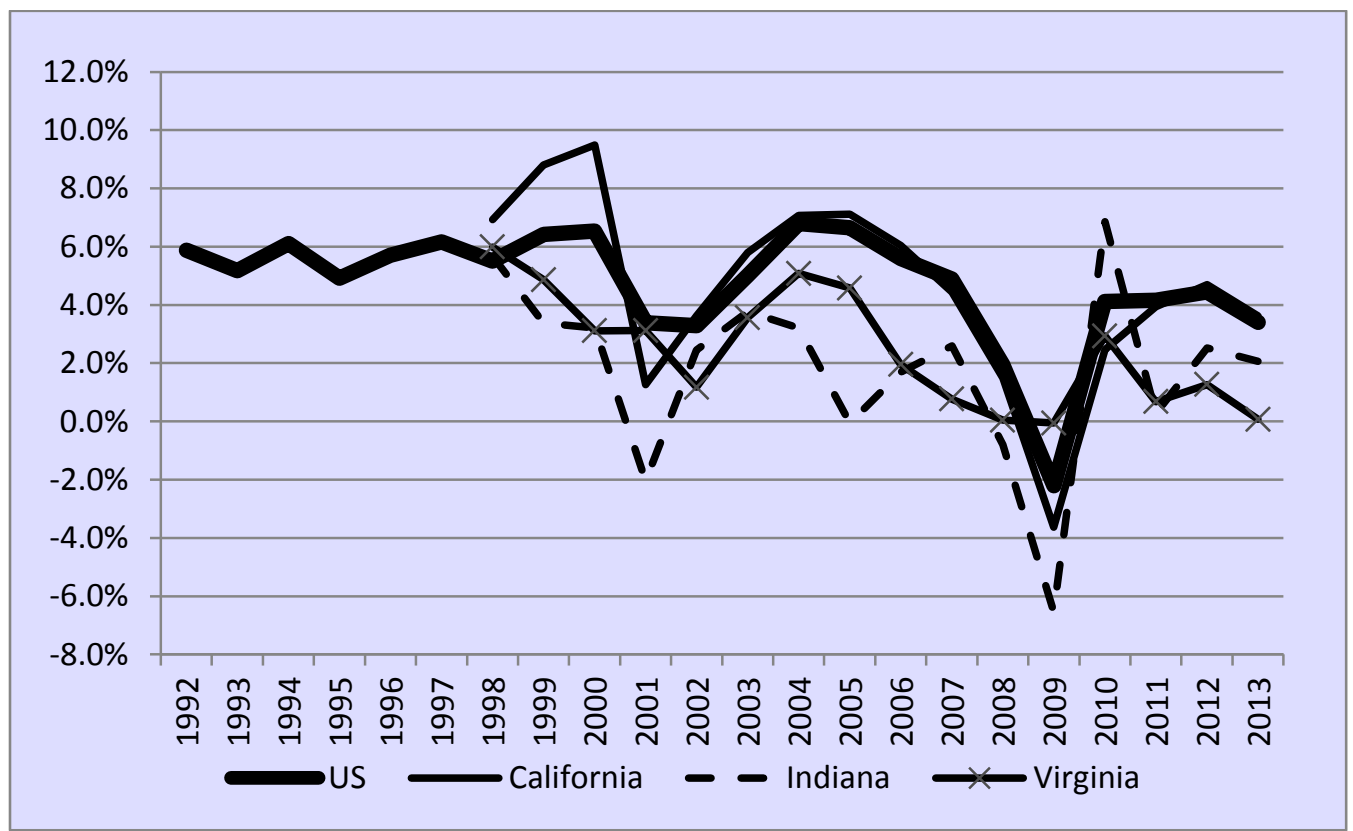

Source: Bureau of Economic Analysis, 2014a; Bureau of Economic Analysis, 2014b. 
Figure 5. Unemployment rates in States with highway P3 renegotiations, 1992-2014

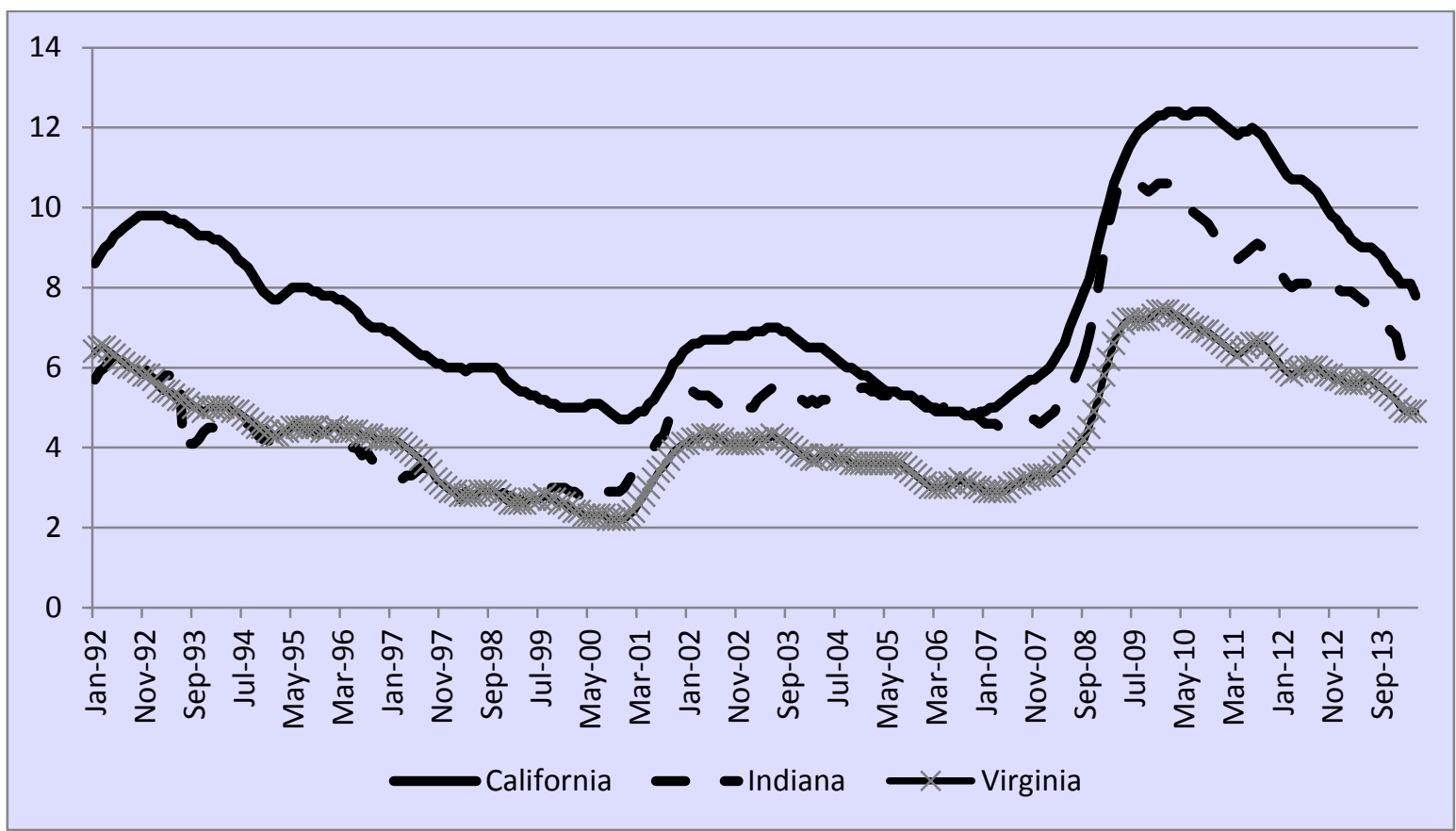

Source: Bureau of Labor Statistics. 2014.

Figure 6. PPI (construction machinery \& iron and steel mills), 1992-2014

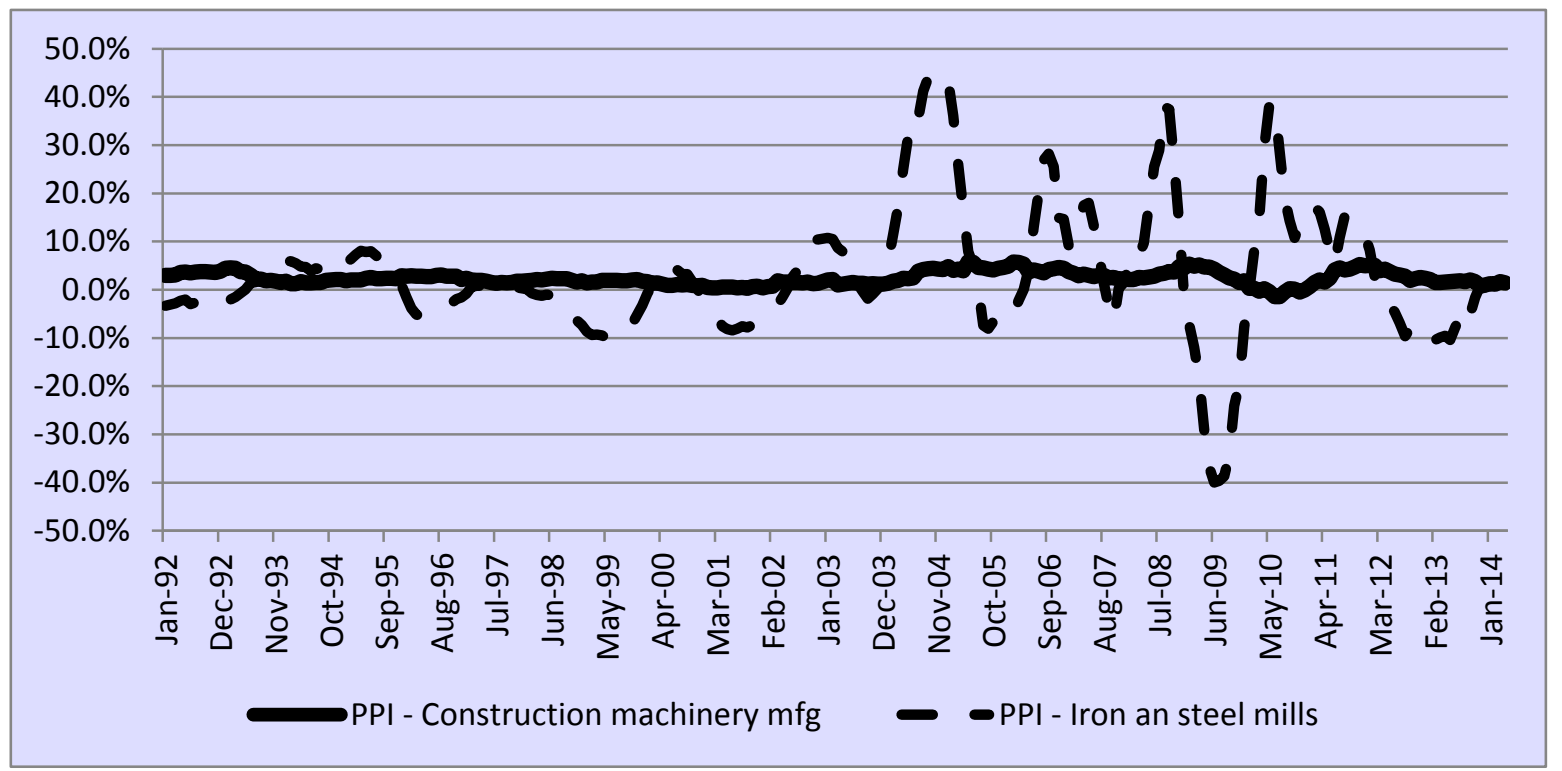

Source: Bureau of Labor Statistics, 2014. 
Figure 7. Prime Bank Loan Rate, not seasonally adjusted (1992-2014)

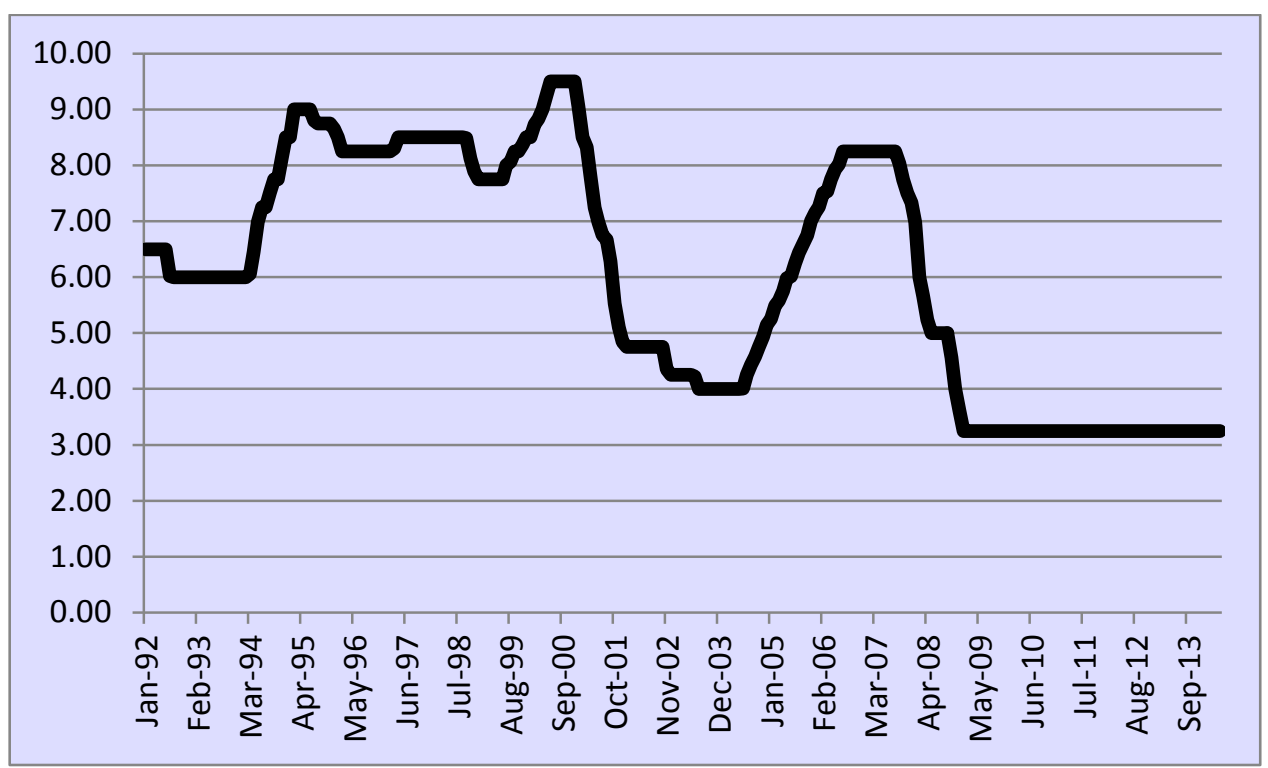

Source: Federal Reserve Bank of St. Louis. 2014. 
